\title{
Does it pay to switch from free grazing to stall feeding? Impact of stall feeding practice on household welfare in Tigrai Ethiopia
}

Muuz Hadush ${ }^{1,2}$ (D)

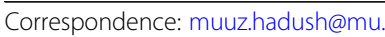
edu.et

'Department of Economics, Mekelle University, P.O. Box 451, Mekelle, Ethiopia

${ }^{2}$ Norwegian University of Life Science (NMBU), Ås, Norway

\begin{abstract}
In this paper, efforts were made to the impact of full and seasonal stall feeding technology on households' economic, ecological, and social welfare outcome indicators in rural Northern Ethiopia using data obtained from the survey of 518 rural farmers. In order to address our primary objective, an endogenous switching regression model was applied. The overall result indicated that SF adoption ensures significant gains in terms of the specified outcome indicators. Using endogenous switching regression models, we estimated different outcome indicators for both adopters from adoption (ATT), and non-adopters had they adopted (ATU). It is identified that there would be a decline of $21 \%$ in milk production and productivity if adopters would not have adopted this technology while non-adopters are estimated to increase their milk production and productivity by 100 and $48 \%$ if they would adopt this technology. The results further show that SF adoption had a significant increment in the lactation period. An increase of consumption expenditure by $17 \%$ from FSF and $44 \%$ in the case of SSF could be considered significant on livelihoods for smallholder farmers. On average, adoption of SF increased manure use in the range of 258-294 kg for adopters. The results showed that SF has decreased the propensity of hiring labor by about $29 \%$ and purchase of animal feed by $31 \%$. We have found that participation in SF, on average, decreased total cattle stock by 1 TLU but increased the probability of keeping milking cow by $23 \%$. The adoption of SF increased the likelihood of participating in an animal sale market by $29 \%$ for adopters and by $47 \%$ for non-adopters had they decided to adopt. The adoption of SF leads to a gain in a number of plants of 11 trees and 29 $\mathrm{m}$ of physical construction for the typical adopter and 36 trees and $133 \mathrm{~m}$ if the typical non-adopter were to adopt the SF technology on their plots. The adoption process also increased the propensity of growing trees by $19 \%$ and decreased household animal shock experience by a probability of 19\% for adopters and about $15 \%$.
\end{abstract}

Keywords: Household welfare, Input use, Animal market participation land investment, Endogenous switching regression, Ethiopia (c) The Author(s). 2021 Open Access This article is licensed under a Creative Commons Attribution 4.0 International License, which permits use, sharing, adaptation, distribution and reproduction in any medium or format, as long as you give appropriate credit to the original author(s) and the source, provide a link to the Creative Commons licence, and indicate if changes were made. The images or other third party material in this article are included in the article's Creative Commons licence, unless indicated otherwise in a credit line to the material. If material is not included in the article's Creative Commons licence and your intended use is not permitted by statutory regulation or exceeds the permitted use, you will need to obtain permission directly from the copyright holder. To view a copy of this licence, visit http://creativecommons.org/licenses/by/4.0/. 


\section{Introduction}

Agriculture is an important motor for realizing economic development in sub-Saharan Africa (SSA). Nearly about $90 \%$ of the poor depend on agricultural productivity to lift them out of poverty (Odame et al. 2013). In rural Africa, livestock is central to human wellbeing. Livestock production plays directly and indirectly in ensuring food security and alleviating poverty (Devereux 2014). Livestock is a primary livelihood source for many low-income rural farmers particularly SSA (FAO 2013). Likewise, manure and traction power derived from livestock production are important outputs to crop production. However, the performance of livestock sector has been poor compared to the other parts of the world due to many binding constraints such as inadequate feed nutrition and poor feeding practices, shrinking natural pastures, animal infection, and weather fluctuation (Odame et al. 2013; FAO 2009).

A large proportion of the rural households in developing countries own livestock, which is valuable financially and plays significant social and economic roles in rural farms (World Bank 2008; Herrero et al. 2013). Livestock contributes to the livelihoods of at least 70\% of Eastern Africa's rural farmers in terms of income and diet (Cecchi et al. 2010). In Ethiopia, the dairy sector plays an important role in the agricultural sector (Tegegne et al. 2013). Livestock is central to the livelihood of the rural poor. It contributes about $12-16 \%$ of the total GDP, and $40 \%$ of total agricultural GDP excluding the values of draught power, transport, and manure, and contributes to the livelihoods of about $60-70 \%$ of the population (Halderman 2004). Milk and milk products play a very important role in feeding the rural and urban people.

Despite the country is said to have a huge potential for livestock production, production per animal is extremely low. Milk production is 1.54 liters per cow per day (CSA 2008). The current per capita consumption of milk and meat is $16 \mathrm{~L}$ and $13.9 \mathrm{~kg} /$ year, respectively; being lower than the African and the world per capita averages, which are $27 \mathrm{~kg} /$ year and $100 \mathrm{~kg} /$ year, respectively (FAO 2009). In addition, it provides 14 million tons of manure annually mainly used for fuel. The value of animal draught power input into arable production is about a quarter $(26.4 \%)$ of the value of annual crop production (Behnke and Metaferia 2011; FAO 2005). As a result, Ethiopia is classified as having the lowest per capita consumption of meat and milk, even among neighboring countries like Kenya.

Recognizing this, improved agricultural technologies are widely considered as the key means of addressing most of low crop and livestock productivity throughout the region (Diao and Pratt 2007). For instance, the use of stall feeding (SF), rotational grazing (RG), or zero grazing (ZG) have been widely recommended across sub-Saharan Africa by policymakers with the objectives of (1) increasing livestock and fodder productivity, (2) halting land degradation, (3) generating income, and (4) minimizing production risks caused by theft, flood, disease, and cattle fighting due to free grazing (Lenaerts 2013; FAO 2007; De Cao et al. 2013; Bishu 2014). These have been practiced in the highlands of Ethiopia, Kenya, Uganda, and Tanzania while its pace of intensification was slower than anticipated throughout the region (Gass and Sumberg 1993; McIntire et al. 1992; Lenaerts 2013; Hadush 2018). The practice of stall feeding along with the improved cows is being promoted in Ethiopia in different phases as potential options for alleviating animal feed shortage problems and increasing livestock productivity (Benin et al. 2006; Klitzing et al. 2014; Lenaerts 2013; De Cao et al. 2013; Bishu 2014; 
Hadush 2018; Hadush and Hagos 2018). The introduction of stall feeding as the system under which cattle are kept at open farmstead permanently and are feed fodder crops, crop residues via 'cut-and-carry system' entails the establishment of garden pastures, breeding, and promoting forage production.

Earlier studies using mean comparison in the region indicated that SF/ZG has several benefits over other extensive grazing systems: SF offers a regular income throughout the year as compared to cash crops (Maarse 1997). It is also linked to better utilization of fodder, increased milk output, better manure management, intensive land use, and low risk of infection by tick-borne diseases, and protection of animals against theft (Bishu 2014; Hadush and Hagos 2018). Besides, Garcia et al. (2008) using qualitative method found that SF in Uganda was economically and ecologically sustainable. Holtland (2007) estimated that cows under ZG practices produce $1.500 \mathrm{~L}$ of milk per lactation of 1.5 years at a cost of $1.000 \mathrm{~h}$ for collecting fodder in Tanzania. Baltenweck et al. (2007) in Tanzania and Staal et al. (2003) from Kenya estimated that ZG was more profitable using simple budget analysis method in Kenya. De Cao et al. (2013) revealed that ZG is a potentially useful practice against low productivity and limited feed availability in Ethiopia.

Wambugu et al. (2011) found that lactation length under SF is 450 days versus 200 days for free grazing. Pre-weaning calf mortality is about $10 \%$ per annum in ZG than $25 \%$ in free grazing. However, about $730 \mathrm{~h}$ of labor per cow per year is required for ZG than $330 \mathrm{~h}$ for free grazing. The average cost of labor per lactating animals was Ksh 745, compared to Ksh 705 in the non-zero grazing system. Similarly, recent studies of Klitzing et al. (2014) in Tigrai indicated that farmers benefit by earning higher income from milk and meat and higher traction power under ZG as compared to traditional grazing. Turinawe et al. (2011) in Uganda and Benin et al. (2006) in Ethiopia also found that farmers that adopted improved breeds also adopted SF. Although SF stall feeding is believed to be profitable, its pace of coverage has been recorded to be slow and low in the region (FAO 2007; Nedessa et al. 2005; Lenaerts 2013; Bishu 2014; Hadush 2018).

One possible reason that the adoption of a new practice has been relatively slow is may be due to its relative advantage it offers (Ghadim et al. 2005: Rogers 2003) and the relatively high cost it entails (Wiebers 1992). Based on Cary et al. (2001), expected profit is a decisive factor in adoption decisions. Ghadim et al. (2005) revealed that the short-term profitability of new legume crops significantly influenced their adoption. D'Emden et al. (2006) found that the adoption of conservation tillage in Australia was influenced by its cost. The economic benefits of SF on household's welfare are neither properly documented nor proper impact evaluation design was followed. The objective of this paper was, therefore, to jointly estimate adoption of SF and evaluate its impact on rural household's welfare indicators ${ }^{1}$ in rural Ethiopia adapting Endogenous Regression model (Lokshin and Sajaia 2004). The paper intends to address the research question of what is the economic impact of SF. To what extent adopters would be worse off if they were non-adopter and how much is the benefits non-adopter would gain had been adopters?

${ }^{1}$ In terms of (1) milk and manure production; (2) milk and meat consumption expenditure; (3) milking cow ownership and total herd size; (4) land conservation and plantation; (5) animal and animal product sale market participation; (6) input use and animal shock 
The outcome equation was estimated using OLS, count, or probit model depending on the type of dependent variable. The uses of ERM allow us to hypothesize that participants would be worse off than non-participants if they decided not to adopt and nonparticipants would benefit more than participants if they were to participate. This is to mean that we anticipate that the predicted impact for adopters will decline from real adoption to hypothetical adoption but will increase from real non-adoption to hypothetical adoption for non-adopters. In line with this expectation, our result showed that there would be a decline in milk production and consumption, lactation period, animal sale, manure use, number of planted trees, and physical structure, but an increase in animal shock exposure, possessing herd size, use of hired labor, and purchase of animal feed had adopters been non-adopters. In the same fashion, milk production and productivity, animal sale, the number of planted trees, and physical structure increased if non-adopters would adopt this technology.

This paper is distinguished from the past related studies in three ways: First, we are perhaps the first to show how stall feeding users compared to non-users are beneficiary using proper evaluation design than prior survey studies which totally neglected the selectivity effects and endogeneity problem. A second is an approach which provides not only a joint estimation of adoption and its impact but also estimates of conditional and unconditional expectation. Third, stall feeding is a new practice in the country whose adoption is recorded to be slow, maybe resulted from non-realization of its positive impacts. Being able to estimate with precision, its impact would influence the types of policies that can be embarked upon the expansion of its coverage.

\section{Literature review}

In Ethiopia, livestock contribution to agricultural GDP accounts for $40 \%$, excluding the values of draft power, manure, and transport service (Asresie and Zemedu 2015). Ethiopia has high-yielding dairy cattle breeds with less animal disease-stress that make it potential for dairy development. The livestock sector is estimated to provide employment to over $30 \%$ of the agricultural labor force. It serves as sources of food traction, manure, raw materials, investment, cash income, security, foreign exchange earnings, and social and cultural identity (CSA 2010). Thus, livestock is a primary livelihood resource for many low-income rural farmers particularly sab-Saharan Africa (FAO 2018). In line with this, Yilma et al. (2011) indicated that livestock production in Ethiopia contributes up to $80 \%$ of farmers' income, about $20 \%$ of agricultural GDP, full-year employment, and share of $16 \%$ to export.

Klitzing et al. (2014) also conducted a comparative study in the highlands of Ethiopia and the result showed that the performance of the sector is challenged primarily by low quality and quantity of feed resources and seasonal fluctuations in feed resources. The average daily milk production was only $1.69 \mathrm{~L}$ with an average lactation length of about 180 days and mean annual milk yield per cow of 305 L. the per capita milk consumption has decreased from $26 \mathrm{~L}$ per annum in 1980 to $22 \mathrm{~L}$ in 1993, $19 \mathrm{~L}$ in 2000, and 16 L in 2009 (Yilma et al. 2011). In spite of large population size, the contribution of livestock production to agriculture and the overall economy of the country is below expected level and is further deteriorating (Gebremedhin et al. 2003; Ilyin 2011; Gebremedhin et al. 2009). 
The practice of SF in Uganda was found to be economically and ecologically sustainable (Garcia et al. 2008). Zero grazing in Tanzania was more economically and environmentally viable wherein improved cows under this practice would produce $1.500 \mathrm{~L}$ of milk per lactation of 1.5 years at a cost of $1.000 \mathrm{~h}$ annually for collecting fodder and water (Holtland 2007) but Meul et al. (2012) in Australia found that zero grazing performed significantly worse from an ecological and economic point of view. A recent study by Klitzing et al. (2014) in Ethiopia revealed that fodder productivity from SF schemes is higher than from FG schemes, leading to overall livestock productivity and higher welfare gain. A survey study conducted by Nyssen et al. (2007) in the region show that modern grazing practices had ecological and economic benefits. Likewise, Hadush and Hagos (2018) using IV 2SLS found that ZG increases milk production and reduces probability of newly born calf death in Tigrai.

Nalunkuuma et al. (2013) indicated that adoption of ZG had a positive impact on farmers' knowledge of cattle farming and breed cow possession in Kenya. De Cao et al. (2013) revealed that ZG was a useful practice to improve cattle productivity and feed availability by reducing free grazing months in Ethiopia. Another result confirmed that almost $80 \%$ of the farmers that adopted improved breeds also adopted stall feeding (Benin et al. 2006). Sserunkuuma (2005) in his study of the adoption of land management technologies in Uganda found that low adoption of improved technology is associated with low profitability. Farmers tend only to use technologies that they consider profitable despite all other non-monetary factors that could deter technology use (Kabirizi 2006). The finding from Turinawe et al. (2011) revealed that farmers using improved forage technology had significantly higher gross profit and a number of improved cows than those using local feeding methods in Uganda. While agronomic benefits of this practice are well documented, economic benefits, however, remained unexplored (Hadush 2018) in the study region.

\section{Theoretical model}

Most SSA countries have also experienced rising population densities in the last decades, resulting in smaller land sizes for crop farming and grazing lands (Headey et al. 2014; Otsuka and Place 2014). Free grazing is an important source of livestock feed (Herrero et al. 2013), where overgrazing becomes the primary cause of low livestock productivity and loss of resilience (Lal and Stewart 2010). Land degradation mainly caused by free grazing takes the lead to adversely affect livestock production by shrinking grazing lands (Tesfa and Mekuriaw 2014). Gebreselassie et al. (2016) have estimated the cost of land degradation in Ethiopia and found that the total annual costs of milk and meat production losses were about $\$ 38$ million and $\$ 2.4$ million respectively in grazing lands. Animals under free grazing system are also exposed to different types of risks such as diseases and deaths due to cattle fighting, theft, predation, flood, and exposure to a high temperature (Bishu 2014). In many parts of Ethiopia, animals have to walk long distances in search of water and feed, resulting in low production and weak oxen power.

Moreover, free grazing system requires higher inputs of labor for feeding and watering, particularly when the natural pastures and stored crop residues begin to diminish. Exploratory studies (e.g., Herrero et al. 2013; Gerber et al. 2011) propose SF intensification to improve livestock productivity and mitigate the environmental problems (Udo 
et al. 2011). The practice of SF increases livestock and fodder productivity and generates sales income through five pathways: halting land degradation; minimizing production risks caused by theft, flood, disease, and cattle fighting due to free grazing; reducing daily walking distance to grazing; helping to improve breeding and feeding system (Lenaerts 2013; FAO 2007; De Cao et al. 2013; Bishu 2014; Hadush and Hagos 2018). Likewise, theoretically confinement of cattle leads to an increased quantities of manure (Rehnström 1999) which are important inputs to crop production. The practice of SF is also ecologically viable and sustainable (Nyssen et al. 2007) by restricting free movement of animals, which has a negative impact on the conservation efforts (stone band, soil band, and plantation) which are being under taken in the region.

In most cases, smallholder farmers make an important decision when they choose to participate in a new intervention. In order to estimate the effect of stall feeding on the outcome of interest, the farm household model in which that household maximize utility subject to income, production, and time constraints (Singh et al. 1986) was adopted as a framework. The choice of this model is based on its merit of integrating the production, consumption, and work decision-making processes of the farm household in a single framework. This paper mainly draws on the ork of Fernandez-Cornejo et al. (2005), who expanded the model of Huffman (1991) to include technology adoption decisions. In this case, the paper focuses on farmers' stall feeding practice.

Farm households are assumed to derive utility $(U)$ from purchased consumption goods $(G)$ and a vector of members' leisure and non-economic activities at home $(L)$. The level of utility obtained from $G$ and $L$ is influenced by exogenous factors such as human capital $(K)$ and other household characteristics $(C)$. Consulting the work of Fernandez-Cornejo et al. (2005), the utility is denoted by:

$$
\operatorname{Max} U=U(G, L ; K, C)
$$

where $U$ is assumed to have the usual regularity properties of a utility function, such as twice differentiability, quasi-concavity, and increasing in $G, L ; K, C$. The objective of the farm household is to maximize utility from the consumption of goods and leisure subject to the farm production, income, and time constraints:

$$
\begin{aligned}
& \text { Time constraint : } T=F(S F)+M+L, M \geq 0 \\
& \text { Production constraint } Q=Q[X(S F), F(S F), K, R], S F \geq 0 \\
& \text { Income constraint : } P_{g} G=P_{q} Q-W_{x} X^{\prime}+W M^{\prime}+A
\end{aligned}
$$

The production technology (3) is assumed to have all the regularity conditions, such as twice differentiable, increasing in inputs, etc. The total household's time endowment $(T)$ is devoted to leisure $(L)$; working on the farm $(F)$; and off-farm work $(M)$, while the farm output level $(Q)$ depends on the quantity of farm inputs $(X)$ such as land, capital, breed cows, feed, etc. and the practice of new feeding (SF), where $S F$ is considered to be labor and feed-saving technology, augmenting and resulting in some free time and money for other activities, F, $K$, and a vector of exogenous variables that shifts the production function $(R)$. The adoption of labor-saving technology SF reduces the labor requirement in cattle farm production. Thus, its adoption should be incorporated into the production technology implicitly as augmenter and not explicitly as a shifter of the 
production function. The adoption of SF is further affected by households' animal shock exposure $(S)$, private social capital $(N)$, household assets $(E), \mathrm{K}$, and $\mathrm{C}$. Thus:

$$
S F=(\mathrm{S}, \mathrm{N}, \mathrm{E}, \mathrm{K}, \mathrm{C}, \mathrm{R})
$$

Equation (4) displays the budget constraint on household income, where $P_{g} G$ is the income available for purchase of consumer goods at a price $P_{g}$, and it depends on the output price $\left(P_{q}\right)$ and quantity $(Q)$ of farm output; vector input prices $\left(W_{x}\right)$ of quantity $(X)$ of farm inputs; off-farm wages $(W)$ and the amount of time spent working off-farm $(M)$ as well as exogenous household income such as private assistance and safety net support $(A)$. Substituting Eq. 3 into Eq. 4 produces a farm technology-constrained measure of household income:

$$
P_{g} G=P_{q} Q[X(S F), F(S F), K, S F, R]-W_{x} X(S F)+W M^{\prime}+A
$$

Maximizing Lagrangian expression $(\mathscr{L})$ over $(\mathrm{G}, \mathrm{L})$ but minimizing it over $(\lambda, \quad)$ yields the Kuhn-Tucker first order conditions:

$$
\begin{aligned}
\mathcal{L}= & U(G, L ; K, C) \\
& +\lambda\left\{P_{q} Q[X(S F), F(S F), K, S F, R]-W_{x} X(S F)+W M^{\prime}+A-P_{g} G\right\} \\
& +\eta[T-F(S F)-M-L]
\end{aligned}
$$

where $\lambda$ and represent the Lagrange multipliers for the marginal utility of income and time respectively. The Kuhn-Tucker first-order conditions are:

$$
\begin{aligned}
& \frac{\partial \mathcal{L}}{\partial G}=U_{G}-\lambda P_{g}=0, \\
& \frac{\partial \mathcal{L}}{\partial L}=U_{G}-\eta=0, \\
& \frac{\partial \mathcal{L}}{\partial S F}=\lambda\left[P_{g}\left\{\frac{\partial Q}{\partial X} * \frac{\partial X}{\partial S F}+\frac{\partial Q}{\partial F} * \frac{\partial F}{\partial S F}\right\}\right]-W_{x} \frac{\partial X}{\partial S F}-\eta \frac{\partial F}{\partial S F}=0 \\
& \frac{\partial \mathcal{L}}{\partial X}=\lambda\left[P_{q} \frac{\partial Q}{\partial X}-W_{x}\right]=0, \\
& \frac{\partial \mathcal{L}}{\partial F}=\lambda P_{q} \frac{\partial Q}{\partial F}-\eta=0 \\
& \frac{\partial \mathcal{L}}{\partial M}=\lambda W-\eta=0 \\
& \frac{\partial \mathcal{L}}{\partial \mathcal{L}}=P_{q} Q[X(S F), F(S F), K, S F, R]-W_{x} X(S F)+W M^{\prime}+A-P_{g} G=0 \\
& \frac{\partial \mathcal{L}}{\partial \eta}=T-F(S F)-M-L=0
\end{aligned}
$$

Based on the Kuhn-Tucker condition solution (Fernandez-Cornejo et al. 2005), we could find the following input demand functions:

$$
X^{*}=\left(W_{x}, P_{q}, S F, W, \mathrm{~K}, \mathrm{C}, \mathrm{T}\right)
$$

Thus, the reduced-form expression of the optimal level of household milk income $\left(\mathrm{Y}^{*}\right)$ can be obtained by substituting the optimal input demand functions into the technology constraint (3) as follows 


$$
\mathrm{Y}^{*}=\left(\mathrm{W}_{\mathrm{x}}, \mathrm{P}_{\mathrm{q}}, \mathrm{SF}, \mathrm{W}, \mathrm{K}, \mathrm{C}, \mathrm{R}, \mathrm{T}\right)
$$

Likewise, solving jointly Eqs. (7.1), (7.2), (7.7) and (9), household demand for consumption goods $(G)$ can be expressed as:

$$
G=\left(S F, P_{g}, P_{q}, \mathrm{Y}^{*}, A, \mathrm{~K}, \mathrm{C}, \mathrm{T}\right)
$$

Thus, the reduced forms of $Y^{*}$ and $G$ are affected by a set of explanatory variables, including SF where this paper is mainly intended to estimate the effect of SF on household milk income, household consumption of milk, and milk products, animal market participation, land conservation, and other related outcome variables such as manure production and lactation period, input use, and shock exposure. This theoretical model and another related empirical evidences have guided the choice of variables in each estimation.

\section{Materials and methods}

\section{Study area and data}

This study used cross-sectional data from Tigrai Rural Household Survey dataset collected in 2015 run by NMBU-MU ${ }^{2}$. Initially, to reflect systematic variation in agroclimatic conditions, agricultural potential, population density, and market access conditions, four communities were selected from each of the four zones and three communities that represent irrigation projects. Likewise, one with low population density and one with high population density were strategically selected from each zone among communities to reflect far distance market (Hagos 2003). The study was conducted in five zones covering 11 districts and 21 Tabias (small administrative unit next to district) so as to yield 632 sample size.

The dataset includes a panel of five rounds conducted in 1997/98, 2000/01, 2002/03, $2005 / 06$, and 2014/2015 where the author is involved only in collecting the data for the last round. A cross-sectional data set for the year 2014/2015 was extracted from the survey since some variables used in this paper were only added in the last wave. The subject interest over stall feeding further reduced the sample size to 518 farmers excluding non- livestock owners during the study year. The descriptive statistics of importance to the study are presented in Table 1 and are discussed in the descriptive statistics result section.

\section{Endogenous switching regression model}

Estimation of the economic gain of the adoption of agricultural technologies such as stall feeding based on non-experimental observations is not trivial because finding a proper counterfactual to treatment is the main challenge in impact evaluation. In experimental studies, this problem is addressed by randomly assigning stall feeding to treatment and control groups. However, this technology is not randomly distributed to both groups. Adoption is rather a voluntary decision where farmers themselves decide to adopt or not to adopt based on the information they have. Therefore, adopters and non-adopters may be systematically different. When comparing adopters with nonadopters, adopters might differ on additional unobservable characteristics such as

${ }^{2}$ Norwegian University of Life science-Mekelle University. This dataset has been initially used by Holden et al. (2011) and Hagos (2003) for their PhD study. 
Table 1 Description and summary statistics for SF adoption decision

\begin{tabular}{|c|c|c|c|}
\hline Description & $\begin{array}{l}\text { Non-adopters } \\
\text { Mean }\end{array}$ & $\begin{array}{l}\text { Adopters } \\
\text { Mean }\end{array}$ & $\begin{array}{l}T \text { test } \\
P \text { value }\end{array}$ \\
\hline Network( assistance from relatives/friends ,ETB ) & 1336.3 & 1508.8 & 0.7023 \\
\hline Gender ( 1 = if household head is male) & .7643 & .8395 & 0.2973 \\
\hline Education ( 1 = if household head is literate) & 3716 & .4545 & 0.0646 \\
\hline Credit ( 1 = if household had access to credit in 2014/2015) & .2416 & .2834 & 0.2973 \\
\hline Cart $(1=$ if household head own cart tool) & .0906 & .1497 & 0.0406 \\
\hline Improved ( 1 = if household head had breed cows) & .0120 & 0.1122 & 0.0000 \\
\hline Information ( 1 = if household own Radio, TV and Mobile) & .1359 & .3048 & 0.0000 \\
\hline Fodder shed ( 1 = if household head own fodder shed) & .0060 & .0320 & 0.0209 \\
\hline Location ( 1 = if household lives above 2000m.a.s.l) & .0664 & .0588 & 0.7329 \\
\hline Distance to nearest road (in walking minute) & 34.38 & 28.27 & 0.0363 \\
\hline Household head age (years) & 57.66 & 57.26 & 028.27 \\
\hline Family labor (h) & 82.31 & 91.19 & 0.1619 \\
\hline Farm income(Ethiopian currency, ETB; 1 \$24 ETB in 2015) & 6689.5 & 5319.7 & 0.3284 \\
\hline Grazing area to household ratio(Ha/number) & .0018 & .0012 & 0.0000 \\
\hline Distance to free grazing (walking minute) & 54.85 & 62.77 & 0.0310 \\
\hline Forage expense (ETB) & 143.59 & 112.2 & 0.1660 \\
\hline Total plots owned by the household (number) & 3.480 & 3.887 & 0.0236 \\
\hline Village Experience of SF(year) & 3.214 & 4.331 & 0.0000 \\
\hline Distance to market (walking minuets) & 79.14 & 78.77 & 0.9407 \\
\hline Off farm income (ETB) & 3638.1 & 6678.8 & 0.2363 \\
\hline Value of all farm tools (ETB) & 549.89 & 797.01 & 0.0625 \\
\hline Farm size(ha) & 1.173 & 1.132 & 0.6835 \\
\hline Distance to nursery (walking minutes) & 59.85 & 58.58 & 0.7863 \\
\hline Feed supplementary expense (ETB) & 144.07 & 112.70 & 0.0071 \\
\hline Total family size (number) & 5.65 & 6.25 & 0.0071 \\
\hline Access to animal shed (yes $=1$ ) & .0574 & .1122 & 0.0246 \\
\hline Veterinary expense (ETB) & 118.2 & 103.88 & 0.2018 \\
\hline \multicolumn{4}{|l|}{ Dependent variables in the first equation } \\
\hline Total herd size (TLU) & 4.078 & 3.953 & 0.6520 \\
\hline Total milk production per household (L/day) & 2.134 & 2.465 & 0.1376 \\
\hline Milk yield (liters per cow per day) & 1.459 & 1.699 & 0.0033 \\
\hline Manure use $(\mathrm{kg})$ per household & 462.9 & 646.9 & 0.2214 \\
\hline Animal shock experience (yes $=1$ ) & 0.157 & 0.283 & 0.0006 \\
\hline Hired labor (yes = 1) & 0.414 & 0.342 & 0.1084 \\
\hline Lactation period (months) & 7.609 & 8.459 & 0.0000 \\
\hline Own milk and milk product consumption expenditure (ETB) & 1549 & 1856 & 0.2101 \\
\hline Animal and animal product market participation (yes $=1$ ) & 0.514 & 0.540 & 0.5626 \\
\hline Animal feed purchase $($ yes $=1$ ) & 0.106 & 0.139 & 0.2597 \\
\hline Length of biophysical construction (m) & 189.35 & 233.8 & 0.4816 \\
\hline Growing trees in plots (yes $=1$ ) & 0.224 & 0.305 & 0.0411 \\
\hline Number of plants planted on household plot (number) & 80.466 & 217.35 & 0.0801 \\
\hline Keeping milking cows (yes $=1$ ) & .6465 & .7272 & 0.0595 \\
\hline
\end{tabular}

Source: own compilation, 2015 
ability, awareness, information, or motivation that could have a direct effect on the outcomes beyond adoption. That is, without stall feeding, outcomes might have been higher for adopters or lower for non-adopters as well, due to unobserved characteristics (Blundell and Costa Dias 2000). Treating adoption as an exogenous variable and applying OLS would result in inconsistent parameter estimate.

The other econometric issue is that even if we account for the endogeneity, it may not be proper to use a pooled model estimation which assumes that the set of covariates has the same impact on adopters and non-adopters. This implies that technology adoption has only an intercept shift effect, which is always the same irrespective of the values taken by other covariates that determine welfare outcome. If it is assumed that covariates have differential effects on household outcome, separate welfare outcome functions for adopters and non-adopters have to be specified, while at the same time accounting for endogeneity. The econometric problem will, therefore, contain both endogeneity (Hausman 1978) and sample selection (Heckman 1979). More generally, the problem is that farmers in each of the two regimes are not the same with respect to variables that are correlated to the error term.

This motivated the researchers to employ an ERM used by Alene and Manyong (2007) following Lokshin and Sajaia (2004) which allows us not only to simultaneously estimate the binary and continuous parts of the model in order to yield consistent standard errors but also to account for both endogeneity and sample selection bias based on joint normality of the error terms assumption.

Basically, ERM has two steps: the first step in the ERM is to specify the selection model so as to determine factors influencing stall feeding adoption based on a probit function by

$$
\begin{gathered}
D_{i}^{*}=Z_{i} \gamma+\varepsilon_{i} \quad \begin{array}{c}
D_{i}=1 \mathrm{if} D_{i}^{*}>0(\text { Adoption of stall feeding }) \\
D_{i}=0 \text { if } D_{i}^{*} \leq 0(\text { non }- \text { adoptionof stall feeding })
\end{array}
\end{gathered}
$$

Where,

$D_{i}^{*}$ is the latent variable for stall feeding adoption, $D_{i}$ is its observable counterpart equals one if the farmer has adopted SF, and zero otherwise, $Z_{i}$ is vectors of exogenous farm and non-farm characteristics determining adoption and $\varepsilon_{i}$ is random disturbances associated with the adoption. The second step in the ERM is to define a separate welfare function for the two groups. The welfare functions can be expressed as:

Regime1 : $\mathrm{Y}_{1 i}=X_{1 i} \beta_{1}+e_{1 i}$ if $\mathrm{D}_{i}=1$ (outcome of stall feeding users)

Regime2 : $\mathrm{Y}_{2 i}=X_{2 i} \beta_{2}+e_{2 i}$ if $\mathrm{D}_{i}=0$ (outcome of non-stall feeding users)

$X_{1}$ and $X_{2}$ are vectors of weakly exogenous variables; $\beta_{1}$ and $\beta_{2}$ are vectors of parameters; and $e_{1}$ and $e_{2}$ are random disturbance terms. $Y_{i}$ represents welfare outcomes measured in terms of milk and manure consumed and sold, lactation and calving period, etc. Unfortunately, both $Y_{1}$ and $Y_{2}$ cannot be observed for a single animal at the same time. But the difference between the two is exactly what we intend to discover, that is, we are interested in (I) the difference between the outcome of the user compared with their expected outcome without stall feeding, and (II) the difference between what nonusers benefit and their expected benefit if they were to adopt stall feeding. The mathematical explanation of these outcomes can be presented as: 


$$
\begin{gathered}
Y_{1 i}-\mathrm{E}\left(Y_{2 i} \mid D_{i}=1\right)(\text { benefit of adopters }) \\
Y_{2 i}-\mathrm{E}\left(Y_{1 i} \mid D_{i}=0\right)(\text { forgone benefit of non-adopters })
\end{gathered}
$$

Assuming that $\varepsilon_{i}, e_{1 i}$, and $e_{2 i}$ have a trivariate normal distribution, with mean vector zero and covariance matrix:

$$
\operatorname{Cov}\left(\varepsilon_{1}, \varepsilon_{2}, \varepsilon_{0}\right)=\left[\begin{array}{ccc}
\sigma_{0}^{2} & \sigma_{01} & \sigma_{02} \\
\sigma_{10} & \sigma_{1}^{2} & \cdot \\
\sigma_{20} & \cdot & \sigma_{2}^{2}
\end{array}\right]
$$

where $\sigma_{1}^{2}$ and $\sigma_{2}^{2}$ are variances of the error terms, $e_{1}$ and $e_{2} ; \sigma_{0}^{2}$ is the variance of the error term, $\varepsilon_{0}$ which can be assumed to be equal to 1 since the coefficients are estimable only up to a scale factor (Lokshin and Sajaia 2004); $\sigma_{10}$ is the covariance of $e_{1}$ and $\varepsilon_{0}$, and $\sigma_{20}$ is the covariance of $\varepsilon_{2}$ and $\varepsilon_{0}$. Since $Y_{1}$ and $Y_{2}$ are never observed simultaneously at the same time in a single cow or ox, the covariance between $\varepsilon_{1}$ and $\varepsilon_{2}$ is not defined and therefore indicated as dots in the covariance matrix and since the error term of the selection equation is correlated with the error terms of the outcome functions, the expected values of $e_{1}$ and $e_{2}$ conditional on the sample selection are non-zero and are defined as:

$$
\begin{aligned}
& E\left[e_{1 i} \mid D_{i}=1\right]=\sigma_{10} \frac{\phi\left(Z_{i} \gamma\right)}{\phi\left(Z_{i} \gamma\right)}=\sigma_{10} \eta_{1 i} \\
& E\left[e_{1 i} \mid D_{i}=0\right]=\sigma_{20} \frac{\phi\left(Z_{i} \gamma\right)}{\phi\left(Z_{i} \gamma\right)}=\sigma_{20} \eta_{2 i}
\end{aligned}
$$

where $\phi($.$) and \Phi($.$) are the standard normal probability density function and normal$ cumulative density function respectively. In this case, a statistical significance of the two estimated covariance, $\hat{\sigma}_{10}$ and $\hat{\sigma}_{20}$ indicates that the decision to adopt and outcome variable are correlated implying the presence of endogenous switching and the null hypothesis of the absence of sample selectivity bias is rejected. Full information maximum likelihood (FIML) method was employed for our estimation as it is a more efficient method of estimating endogenous switching regression models (Lokshin and Sajaia 2004). The logarithmic likelihood functions are given the assumption of trivariate normal distribution for the error terms:

$$
\ln L_{i}=\sum_{i=1}^{N}\left\{D_{i}\left[\ln \phi\left(\frac{e_{1 i}}{\sigma_{1}}\right)-\ln \sigma_{1}+\ln \Phi\left(\theta_{1 i}\right)\right]+\left(1-D_{i}\right)\left[\ln \phi\left(\frac{e_{2 i}}{\sigma_{2}}\right)-\ln \sigma_{2}+\ln \left(1-\Phi\left(\theta_{2 i}\right)\right)\right]\right\}
$$

where $\theta_{j i}=\frac{Z_{i} \gamma+\rho_{j} \varepsilon_{j i} / \sigma_{j}}{\sqrt{1-\rho_{j}^{2}}} \frac{1}{2}$, with $j=1,2$, and $\rho_{j}$ represents the correlation coefficient between the error terms $\varepsilon_{i}$, of the selection model and the error terms $e_{1 i}$ and $e_{2 i}$ of the outcome equation. Even if there is only one dependent variable, the set of exogenous variables in the first regression might be different from the set of exogenous variables in the second regression. Hence, both equations must be specified (Lokshin and Sajaia 2004). In addition, we followed the usual order condition that $Z_{i}$ contain at least one variable not in $X_{i}$ imposing an exclusion restriction on Eq. (13). These variables do not have any direct effect on the outcome variable, although they are hypothesized to affect the probability that the household adopts improved technology.

The use of endogenous switching regression model has an additional advantage in comparing the expected outcome of adopters (I) with respect to the households that 
did not adopt (II), and to investigate the expected outcome in the counterfactual hypothetical cases (III) that the adopted households did not adopt, and (d) that the nonadopters households adopted. Thus, the conditional expectations for our outcome variables in the four cases are denoted as:

(I) $E\left(Y_{1 i} \mid D_{i}=1\right)=X_{1 i} \beta_{1}+\sigma_{10} \eta_{1 i}$

(II) $E\left(Y_{2 i} \mid D_{i}=0\right)=X_{2 i} \beta_{2}+\sigma_{20} \eta_{2 i}$

(III) $E\left(Y_{2 i} \mid D_{i}=1\right)=X_{1 i} \beta_{2}+\sigma_{20} \eta_{1 i}$

(IV) $E\left(Y_{1 i} \mid D_{i}=0\right)=X_{2 i} \beta_{1}+\sigma_{10} \eta_{2 i}$

Cases (I) and (II) indicate the actual expectations observed in the sample, whereas cases (III) and (IV) represent the counterfactual expected outcomes. Furthermore, the effect of the treatment 'to adopt' on the treated (TT) is calculated as the difference between (I) and (III), and the effect of the treatment of the untreated (TU) for the households that actually did not adopt as the difference between (IV) and (II) following the procedures used by Heckman (2001) and Di Falco and Veronesi (2013) that compares the performance of climate change adaptation strategies in Ethiopian agriculture via calculating ATT and ATU:

$$
\begin{aligned}
& \text { (II) } T T=E\left(Y_{1 i} \mid D_{i}=1\right)-E\left(Y_{2 i} \mid D_{i}=1\right)=X_{1 i}\left(\beta_{1}-\beta_{2}\right)+\left(\sigma_{10}-\sigma_{20}\right) \eta_{1 i} \\
& \text { (III) } T U=\left(Y_{1 i} \mid D_{i}=0\right)-E\left(Y_{2 i} \mid D_{i}=0\right)=X_{2 i}\left(\beta_{1}-\beta_{2}\right)+\left(\sigma_{10}-\sigma_{20}\right) \eta_{2 i} \\
& \text { (IV) } B H_{1}=\left(Y_{1 i} \mid D_{i}=1\right)-E\left(Y_{1 i} \mid D_{i}=0\right)=\left(X_{1 i}-X_{2 i}\right) \beta_{1 I}+\sigma_{10}\left(\eta_{1 i}-\eta_{2 i}\right) \\
& \text { (V) } B H_{2}==\left(Y_{1 i} \mid D_{i}=1\right)-E\left(Y_{2 i} \mid D_{i}=1\right)=\left(X_{1 i}-X_{2 i}\right) \beta_{2 I}+\sigma_{20}\left(\eta_{1 i}-\eta_{2 i}\right)
\end{aligned}
$$

\section{Results and discussions}

\section{Descriptive statistics}

Table 1 presents the basic socio-economic characteristics of 518 livestock ownerfarmers drawn from a total of 632 sample farmers. The outcome variables in this paper include households' milk and dung production; animal product (milk, butter, cheese, yogurt, and dung) consumption, animal sale market participation, lactation length, animal shock incidence, input use (feed and labor), land conservation (planted trees and constructed structures) during the survey production year. As noted earlier, adopters are classified as farmers that feed at least one cattle in the full year (FSF) ${ }^{3}$ or in an at least single season (SSF) during the survey period, while non-adopters are farmers that follow traditional free grazing system. The result showed that the percentage of full adopters and non-users in the full year round is reported to be $36.10 \%$ and $63.9 \%$ respectively. However, farmers practicing SF at least in one season are $55.6 \%$, whereas those non-users are $44.4 \%$ in the study area. Table 1 reports summary statistics for the selected outcome indicators and key household characteristics. Adopters of SF are seemingly better off than non-adopters in many aspects.

The average milk yield of a dairy cow in the study area is estimated at 1, 69 for adopters and $1.46 \mathrm{~L}$ per cow per day for non-adopters, which is much lower than in neighboring Kenya (Wambugu et al. 2011). With regard to the total milk, adopters on average harvest more than $1 \mathrm{~L}$ per cow per day as compared to non-adopters.

${ }^{3}$ Stall Feeding (SF) adoption in this paper is defined as the practice of feeding some or all animals in an open homestead land. Full Stall Feeding (FSF) adoption is the practice of stall feeding some or all animals in in a full-year round and Seasonal Stall Feeding (SSF) is for at least one season of the year. SF can be applied in a single season or in a full year term. It is also possible that a farmer can allocate his milking cows to SF while his oxen to free grazing (Lenaerts 2013). 
Moreover, adopters are more likely to be involved in animal and animal product markets than non-adopters, with adopters having 54\% compared to non-adopters, $51 \%$. Adopters have a significantly higher annual milk and meat consumption expenditure, lactation period as well as higher dung production. These all indicators point to the fact that adopters are likely more beneficiary than non-adopters.

Adopters also have a higher number of milking cow but a lower number of hired labor and fodder, implying that adopters can save more input such as labor and feed. As expected, the same statistical analysis result shows that adopting farmers have lower herd size than non-adopters. Shock exposure for adopters is relatively higher ranging from $16 \%$ for non-adopters and $28 \%$ for adopters. The propensity to plant is much higher in adopters, with a difference of $8 \%$ between adopters and non-adopters. Regarding land investment, adopter on average constructed $233.8 \mathrm{~m}$ of stone bunds in the form of soil conservation and planted 217 trees on their plot as compared to nonadopters who only construct $189 \mathrm{~m}$ of stone bunds and planted 80 trees, indicating SF motivates for soil water conservation and hence, soil fertility.

Adopters of SF had a higher number of family members, number of plots, better access to a mobile telephone, and reside close to the nearest road than non-adopters. Adopters of SF were mainly male-headed, had higher access to formal credit, and reside far away from the free grazing area than non-adopters. Yet another comparison shows that education level, grazing area ratio, SF exposure, and access to fodder shed and animal shed are significantly different between adopters and non-adopters. Specifically, adopters have more literacy rate and significantly more SF exposure, access to fodder, and animal shed. Contrary to expectations, adopters also have a higher value of farm tool and a lower feed supplementary expense than non-adopters. Adopters have more than twice as much breed cows and farm cart as their non-adopting counterparts.

\section{Empirical result}

We first focus on the adoption of SF in the selection Eq. (11). Second, we explain the factors affecting the outcome variables estimated by Eq. (12), depending on whether farmers are adopters and non-adopters. Finally, we estimate ATT for adopters and ATU for non-adopters by Eq. (16). The estimates of the determinants of adoption and outcome variables are presented in Tables 2, 3, 4, 5, 6 and 7.

\section{Impact of FSF adoption on milk production and manure production}

As noted previously, the FIML method estimates both the adoption and the outcome equations jointly. Results from the selection equations are discussed first. The estimated results for the probability of adopting the technology are generally in agreement with our earlier expectation. In all specifications, the same variables almost have statistically similar effects on adoption. $\rho_{1}$ and $\rho_{2}$, the correlation coefficients between the error terms of the selection and outcome equations are reported at the bottom section of the same table as an indication of selection bias. A statistical significance of any of them signaled to account for self-selection issue. The correlation coefficients for the adopters $\left(\rho_{1}\right)$ and non-adopters $\left(\rho_{2}\right)$ equations are both negative but statistically insignificant, suggesting that both groups are not better or worse off than a random farm household. The insignificance of the likelihood ratio tests for independence of 
Table 2 Endogenous switching for FSF adoption and milk production

\begin{tabular}{|c|c|c|c|}
\hline \multirow[t]{2}{*}{ Variables } & \multirow{2}{*}{$\begin{array}{l}(\mathrm{FSF}=1) \\
\text { Milk yield }\end{array}$} & \multirow{2}{*}{$\begin{array}{l}(\mathrm{FSF}=0) \\
\text { Milk yield }\end{array}$} & \multirow{2}{*}{$\begin{array}{l}(\mathrm{FSF}=1 / 0) \\
\text { Selection }\end{array}$} \\
\hline & & & \\
\hline Province5 (South East) & $-0.463(0.309)$ & $-0.770^{* * *}(0.182)$ & $0.948^{* *}(0.370)$ \\
\hline Province 3 (Central) & $-0.748^{* * *}(0.270)$ & $-0.826^{* * *}(0.275)$ & $1.564^{* * *}(0.396)$ \\
\hline Province 2 (Eastern) & $-0.683^{* * *}(0.222)$ & $-0.887^{* * *}(0.187)$ & $0.760^{* *}(0.353)$ \\
\hline Province 4 (North west) & $-0.396(0.257)$ & $-0.685^{* * *}(0.143)$ & $0.458^{*}(0.252)$ \\
\hline Total cows (count) & $0.0316(0.0618)$ & $-0.0367(0.0268)$ & $-0.0534(0.0690)$ \\
\hline Hired labor (yes = 1) & $0.138(0.140)$ & $-0.240^{* * *}(0.0902)$ & $0.0499(0.178)$ \\
\hline Grazing area to household ratio (ha/hh) & $48.27^{* *}(24.02)$ & $13.99(13.73)$ & $-35.00(49.72)$ \\
\hline Total animal feed value(ETB) & $-9.02 \mathrm{e}-06(1.01 \mathrm{e}-05)$ & $1.06 \mathrm{e}-05(8.00 \mathrm{e}-06)$ & $3.43 e-05^{* * *}(1.15 e-05)$ \\
\hline Forage expense (ETB) & $-0.0657(0.159)$ & $-0.00264(0.114)$ & $0.357^{*}(0.183)$ \\
\hline Feed supplementary cost (ETB) & $0.000250(0.000154)$ & $-0.000161^{* * *}(5.25 e-05)$ & $-1.00 \mathrm{e}-05(0.000153)$ \\
\hline Veterinary expense (ETB) & $-0.00144(0.00148)$ & $0.000406(0.000263)$ & $-0.000599(0.000755)$ \\
\hline Location (highland = 1) & $0.241(0.237)$ & $0.155(0.206)$ & $-0.754^{*}(0.448)$ \\
\hline Improved cow (yes $=1$ ) & $0.471^{*}(0.278)$ & $-0.381(0.271)$ & $1.556^{* * *}(0.383)$ \\
\hline Access to pond (yes $=1$ ) & $-0.140(0.200)$ & $-0.387^{*}(0.233)$ & $-0.449(0.767)$ \\
\hline Access to animal shed (yes $=1$ ) & $0.520^{* *}(0.209)$ & $-0.161(0.141)$ & $0.336(0.334)$ \\
\hline Access to fodder shed (yes $=1$ ) & $-0.534^{* * *}(0.161)$ & $-0.605^{* *}(0.255)$ & $1.732^{* *}(0.699)$ \\
\hline Household head age (year) & $0.000937(0.00523)$ & $0.00166(0.00289)$ & $-0.00430(0.00578)$ \\
\hline Animal shock exposure (yes $=1$ ) & $-0.122(0.177)$ & $0.189(0.116)$ & $0.473^{* *}(0.188)$ \\
\hline Family labor (h) & $0.00203(0.00123)$ & $0.00107^{*}(0.000550)$ & $0.000891(0.00105)$ \\
\hline Information access (yes $=1$ ) & & & $0.381^{* *}(0.186)$ \\
\hline Village exposure to SF(years) & & & $0.144^{* *}(0.0705)$ \\
\hline Constant & $2.081^{* * *}(0.381)$ & $1.863^{* * *}(0.182)$ & $-1.638^{* * *}(0.464)$ \\
\hline Ins1, Ins2 & $-0.271(0.132)^{* *}$ & $-0.556(0.164)^{* * *}$ & \\
\hline$\rho_{1}, \rho_{2}$ & $-0.363(0.266)$ & $0.166(0.354)$ & \\
\hline LR test of indep. eqns (PV & & 0.2058 & \\
\hline Observations & 364 & 364 & 364 \\
\hline
\end{tabular}

$P$ values are for slopes: ${ }^{* *} P<0.01,{ }^{* *} P<0.05$, and ${ }^{*} P<0.10=$ significant at $1 \%, 5 \%$, and $10 \%$ probability level, respectively

equations also proved that there is no joint dependence between the selection equations and the outcome equations for adopters and non-adopters (Table 2).

The selection model results are only discussed briefly as our main objective is to evaluate the impacts on different outcomes. Column (3) of Table 2 shows that the factors influencing the household decision to participate in FSS are zonal variation and access to information, animal feed shed, breed cow, village exposure to SF, animal shock and location, forage use, and total feed value. The variable representing information is positive and significantly different from zero, suggesting that more-informed farmers are more likely to adopt FSF, consistent with the findings of Gunte (2015), who revealed a positive relationship between access to information and forage adoption and Deressa et al. (2009), who discovered a positive climate change adaptation strategy and information in Ethiopia. The variable access to animal feed shed is also positive and statistically significant in the selection model, indicating that farmers with feed shed are more likely to adopt the technology. The finding concurs with findings of Gebremedhin 
Table 3 Endogenous switching for FSF adoption and milk and meat consumption expenditure

\begin{tabular}{|c|c|c|c|}
\hline \multirow[t]{2}{*}{ Variables } & \multirow{2}{*}{$\begin{array}{l}(\mathrm{FSF}=1) \\
\text { Consumption }\end{array}$} & \multirow{2}{*}{$\begin{array}{l}(\mathrm{FSF}=0) \\
\text { Consumption }\end{array}$} & \multirow{2}{*}{$\begin{array}{l}(\mathrm{FSF}=1 / 0) \\
\text { Selection }\end{array}$} \\
\hline & & & \\
\hline Family size (count) & $18.36(98.52)$ & $31.65(47.64)$ & $0.0445(0.0332)$ \\
\hline Household head sex $($ male $=1)$ & $751.5^{* *}(341.2)$ & $-102.2(262.0)$ & $0.401^{*}(0.214)$ \\
\hline Household head age (year) & $-16.44(10.13)$ & $5.832(8.664)$ & $-0.00239(0.00513)$ \\
\hline Household head education (literate $=1$ ) & $-374.3(362.6)$ & $-99.19(298.7)$ & $0.0350(0.155)$ \\
\hline Total food expenditure (ETB) & $0.0823^{* * *}(0.0208)$ & $0.0413^{* * *}(0.0138)$ & $1.81 \mathrm{e}-06(3.19 \mathrm{e}-06)$ \\
\hline Farm size (ha) & $-63.41(84.29)$ & $71.42(155.7)$ & $0.0310(0.0582)$ \\
\hline Total farm income (ETB) & $0.0401(0.0381)$ & $-0.00273(0.00253)$ & $-7.93 \mathrm{e}-06(6.06 \mathrm{e}-06)$ \\
\hline Total off farm income (ETB) & $0.0226(0.0187)$ & $-0.00336(0.00315)$ & $-3.90 \mathrm{e}-06(5.67 \mathrm{e}-06)$ \\
\hline Religion of household head (Orthodox $=1$ ) & $-593.2(623.1)$ & $-51.60(317.1)$ & $0.488^{* *}(0.211)$ \\
\hline Location of household (highland = 1) & $713.0(791.4)$ & $-174.8(203.5)$ & $-1.080^{* *}(0.451)$ \\
\hline Information access (TV, radio, and mobile $=1$ ) & $148.6(395.2)$ & $124.4(357.8)$ & $0.546^{* * *}(0.183)$ \\
\hline Herd size (TLU) & $155.4^{* * *}(59.18)$ & $186.9^{* * *}(49.73)$ & $-0.0216(0.0237)$ \\
\hline Access to formal credit (yes $=1$ ) & $737.2(482.0)$ & $122.5(272.3)$ & $-0.0302(0.168)$ \\
\hline Animal shock experience (yes $=1$ ) & $-182.0(363.8)$ & $-130.3(362.8)$ & $0.338^{*}(0.183)$ \\
\hline Distance to free grazing land (walking minute) & & & $0.00168(0.00183)$ \\
\hline Exposure of SF(years) & & & $0.322^{* * *}(0.0560)$ \\
\hline Constant & $1038(1251)$ & $-261.2(503.9)$ & $-2.587^{* * *}(0.503)$ \\
\hline $\operatorname{lns} 1, \operatorname{lns} 2$ & $7.552(0.045)^{* * *}$ & $7.527(0.0001)^{* * *}$ & \\
\hline$\rho_{1}, \rho_{2}$ & $-0.318(0.280)$ & $0.0023(0.124)$ & \\
\hline LR test of indep. eqns (PV & & 0.1434 & \\
\hline Observations & 364 & 364 & 364 \\
\hline
\end{tabular}

$P$ values are for slopes: ${ }^{* *} P<0.01,{ }^{*} P<0.05$, and ${ }^{*} P<0.10=$ significant at $1 \%, 5 \%$, and $10 \%$ probability level, respectively

et al. (2003) which have shown that the access to own animals' feed significantly increases the adoption of high-yielding farming varieties.

The possession of improved cow and animal shock exposure, forage expense, and total feed value are statistically significant variables with a positive sign, inducing farming households to adopt SF technology. As noted by Turinawe et al. (2011) in Uganda, adoption of SF was significantly and positively influenced by the number of breed cows, and relevant findings of Holden and Westberg (2016) indicated that cereal plantation and fertilizer application were positively correlated with risk aversion for net buyers of food in Ethiopia. Ayenew et al. (2015) found that farmers with a higher level of relative risk premium were more likely to opt for crop diversification In Ethiopia. Gebremedhin et al. (2003) found that the quantity of straw output encouraged forage adoption, suggesting a complementary role for forage in supplementing other feed resources in Ethiopia. Farmers living in the lowlands area showed more interest in the SF use and this opposes the results of Bishu (2014) once zonal variation is controlled.

Smallholder farmers in Ethiopia mainly depend on green pasture-size of grazing land per household and crop residue to feed their animals (Tegegne et al. 2013). The estimation results show that grazing area ratio, access to animal feed shed, and breed cow positively affect the milk production of adopters. An increase in grazing area per household results in higher milk for adopters while breed cow holding contributes positively 
Table 4 Endogenous switching for FSF adoption and milking cows ownership

\begin{tabular}{|c|c|c|c|}
\hline \multirow[t]{2}{*}{ Variables } & \multirow{2}{*}{$\begin{array}{l}\text { (FSF }=1) \\
\text { Milking cow }\end{array}$} & \multirow{2}{*}{$\begin{array}{l}(\mathrm{FSF}=0) \\
\text { Milking cow }\end{array}$} & \multirow{2}{*}{$\begin{array}{l}(\mathrm{FSF}=1 / 0) \\
\text { Selection }\end{array}$} \\
\hline & & & \\
\hline Education status (literate $=1$ ) & $-0.00974(0.255)$ & $-0.0382(0.198)$ & $-0.00268(0.133)$ \\
\hline Household head age (year) & $-0.0112(0.00823)$ & $-0.00392(0.00605)$ & $-0.00279(0.00442)$ \\
\hline Household head sex $($ male= $=1)$ & $0.0423(0.325)$ & $0.122(0.212)$ & $0.345^{* *}(0.175)$ \\
\hline Family size (number) & $-0.0457(0.0537)$ & $-0.0543(0.0421)$ & $0.0640^{* *}(0.0285)$ \\
\hline Farm size (ha) & $0.360^{*}(0.202)$ & $0.200(0.126)$ & $-0.0110(0.0523)$ \\
\hline Farm income (ETB) & $-9.62 \mathrm{e}-06(1.00 \mathrm{e}-05)$ & $\begin{array}{l}1.31 e-05^{* *}(5.54 e- \\
06)\end{array}$ & $\begin{array}{l}-4.91 e-06(3.75 e- \\
06)\end{array}$ \\
\hline Off farm income (ETB) & $-1.11 \mathrm{e}-06(2.21 \mathrm{e}-06)$ & $5.71 \mathrm{e}-06(6.53 \mathrm{e}-06)$ & $\begin{array}{l}3.61 e-06^{* *}(1.69 e- \\
06)\end{array}$ \\
\hline Access to formal credit (yes $=1$ ) & $-0.329(0.259)$ & $-0.464^{* *}(0.210)$ & $-0.00167(0.142)$ \\
\hline $\begin{array}{l}\text { Information access (TV, radio, and mobile }= \\
\text { 1) }\end{array}$ & $-0.393(0.297)$ & $-0.612^{* *}(0.279)$ & $0.528^{* * *}(0.155)$ \\
\hline Herd size (TLU) & $0.406^{* * *}(0.0898)$ & $0.695^{* * *}(0.111)$ & $-0.0355(0.0248)$ \\
\hline Forage use (yes $=1$ ) & $0.0865(0.273)$ & $-0.0842(0.248)$ & $0.359^{* *}(0.154)$ \\
\hline Feed supplementary expense (ETB) & $0.000396(0.000291)$ & $\begin{array}{l}-0.000115 \\
(0.000108)\end{array}$ & $2.52 \mathrm{e}-05(9.99 \mathrm{e}-05)$ \\
\hline Veterinary expense (ETB) & $\begin{array}{l}-0.00182^{* * *} \\
(0.000683)\end{array}$ & $\begin{array}{l}-0.000205 \\
(0.000947)\end{array}$ & $\begin{array}{l}-0.000835 \\
(0.000706)\end{array}$ \\
\hline Location of household (highland $=1$ ) & $-0.545(0.413)$ & $-0.963^{* *}(0.477)$ & $-0.963^{* * *}(0.344)$ \\
\hline Family labor (h) & $-0.000733(0.00195)$ & $-0.00256(0.00184)$ & $0.00149(0.000949)$ \\
\hline Hired labor (h) & $0.394(0.315)$ & $-0.221(0.186)$ & $-0.0872(0.139)$ \\
\hline Animal shock experience (yes $=1$ ) & $0.215(0.278)$ & $-0.113(0.244)$ & $0.421^{* * *}(0.150)$ \\
\hline Distance to market (walking minutes) & $0.00104(0.00246)$ & $0.00233(0.00154)$ & $2.01 \mathrm{e}-05(0.00110)$ \\
\hline Distance to nearest road (walking minutes) & $-0.00403(0.00495)$ & $0.00226(0.00244)$ & $-0.00297^{*}(0.00179)$ \\
\hline Exposure of SF (year) & & & $0.351^{* * *}(0.0472)$ \\
\hline Constant & $-0.146(1251)$ & $-1.504^{* * *}(503.9)$ & $-2.125^{* * *}(0.416)$ \\
\hline rhol, rho0 & $0.475(0.331)$ & $-0.488(0.227)^{* *}$ & \\
\hline LR test of indep. eqns (PV & & 0.1354 & \\
\hline Observations & 518 & 518 & 518 \\
\hline
\end{tabular}

$P$ values are for slopes: ${ }^{* *} P<0.01,{ }^{*} P<0.05$, and ${ }^{*} P<0.10=$ significant at $1 \%, 5 \%$, and $10 \%$ probability level, respectively

to milk harvest. Makoni et al. (2014) argue that the increase in milk production may have come mainly from an increased number of cows rather than increased productivity while Adane et al. (2015) indicated that higher grazing land and number of breed cows per household were positively associated with the higher the milk output in Ethiopia.

The variables hired labor and family labor had opposite signs with hired labor having a negative effect and family labor with a positive effect on outputs of nonadopters. Adane et al. (2015) and Del Corral et al. (2011) found that there is a strong relationship between family labor and milk production. In addition, the zonal variation in which household reside determines the level of household milk production for both groups negatively. The availability of fodder shed and purchased supplements are also found to have unexpected negative effects on milk production mainly for adopters. This result is inconsistent with other studies on milk production (Adane et al. 2015; Del Corral et al. 2011). 
Table 5 Endogenous switching for FSF adoption and propensity to plant

\begin{tabular}{|c|c|c|c|}
\hline \multirow[t]{2}{*}{ Variables } & \multirow{2}{*}{$\begin{array}{l}(\mathrm{FSF}=1) \\
\text { Propensity to } \\
\text { plant }\end{array}$} & \multirow{2}{*}{$\begin{array}{l}(\mathrm{FSF}=0) \\
\text { Propensity to } \\
\text { plant }\end{array}$} & \multirow{2}{*}{$\begin{array}{l}(\mathrm{FSF}=1 / 0) \\
\text { Selection }\end{array}$} \\
\hline & & & \\
\hline Family size (number) & $0.0877(0.0580)$ & $0.0922^{* *}(0.0424)$ & $0.0718^{* *}(0.0281)$ \\
\hline Household head age (year) & $0.0157^{* *}(0.00789)$ & $0.00745(0.00612)$ & $-0.00516(0.00446)$ \\
\hline Household head sex (male $=1)$ & $-0.0956(0.309)$ & $-0.160(0.234)$ & $0.427^{* *}(0.183)$ \\
\hline Household head education (literate $=1$ ) & $0.214(0.226)$ & $0.104(0.184)$ & $-0.0620(0.139)$ \\
\hline $\begin{array}{l}\text { Distance to nearest nursery (walking } \\
\text { minutes) }\end{array}$ & $\begin{array}{l}-0.00501^{* *} \\
(0.00216)\end{array}$ & $-0.00360^{*}(0.00201)$ & $0.000621(0.00133)$ \\
\hline Social network( got assistance=1) & $-3.13 e-06(2.60 e-05)$ & $-2.62 \mathrm{e}-05(2.53 \mathrm{e}-05)$ & $7.09 e-06(1.21 e-05)$ \\
\hline Farm size(ha) & $0.0906(0.0575)$ & $0.0463(0.109)$ & $0.00148(0.0532)$ \\
\hline Herd size(TLU) & $-0.00372(0.0391)$ & $-0.0267(0.0331)$ & $-0.0274(0.0241)$ \\
\hline $\begin{array}{l}\text { Information access (TV, radio, and mobile }= \\
\text { 1) }\end{array}$ & $0.0354(0.272)$ & $-0.0538(0.283)$ & $0.536^{* * *}(0.163)$ \\
\hline Family Labor (h) & $0.00270(0.00181)$ & $0.00212^{*}(0.00115)$ & $0.000698(0.000917)$ \\
\hline Hired Labor (yes = 1) & $-0.726^{* * *}(0.264)$ & $-0.229(0.194)$ & $-0.119(0.140)$ \\
\hline Location of household (highland $=1$ ) & $-0.0732(0.416)$ & $0.0230(0.341)$ & $-0.944^{* * *}(0.332)$ \\
\hline Access to animal cart (yes $=1$ ) & $0.0314(0.281)$ & $-6.662^{* * *}(0.309)$ & $0.430^{* *}(0.202)$ \\
\hline Distance to district office (walking minutes) & $-0.000628(0.00129)$ & $0.00152(0.00106)$ & $\begin{array}{l}-0.00123 \\
(0.000763)\end{array}$ \\
\hline Willingness to invest in trees (yes $=1$ ) & $-0.280(0.231)$ & $-0.490^{* * *}(0.180)$ & $-0.00472(0.131)$ \\
\hline Animal shock experience (yes $=1$ ) & & & $0.380^{* *}(0.156)$ \\
\hline Exposure of SF (year) & & & $0.326^{* * *}(0.0492)$ \\
\hline Constant & $-1.674^{* *}(0.705)$ & $-1.537^{* * *}(0.531)$ & $-1.939^{* * *}(0.431)$ \\
\hline rhol, rho0 & $0.0798(0.331)$ & $-0.388(0.588)$ & \\
\hline LR test of indep. eqns (PV & & 0.6843 & \\
\hline Observations & 518 & 518 & 518 \\
\hline
\end{tabular}

$P$ values are for slopes: ${ }^{* *} P<0.01,{ }^{* *} P<0.05$, and ${ }^{*} P<0.10=$ significant at $1 \%, 5 \%$, and $10 \%$ probability level, respectively

Estimated impacts of FSF and SSF adoption are presented in Table 8. The predicted outcomes from the ESR models are used to compute both the average treatment effect on the treated (ATT) and average treatment effect on the non-treated (ATU). ESR results also demonstrate that SF has mixed impacts on economic indicators. We estimated endogenous switching regression (ESR) to control for selection bias from both observable and unobservable factors by the full information maximum likelihood (FIML) method (Lokshin and Sajaia 2004) and model results are presented in Table 8.

Considering the case of full adoption (FSF), households that adopted SF would have harvested 0.39 (21.7\%) liters/cow less in the case of FSF and $2 \mathrm{~L} /$ cow in the case of SSF had they not adopted; their lactation period would have declined by 0.29 (3.5\%) months respectively. Had non-participants chosen to adopt, they would have increased their milk harvest by $2.3 \mathrm{~L}$ per cow and their lactation period would have increased by 1 month. The result that SF positively influences milk production and lactation is a confirmation that SF contributes to the first action of climate-smart agriculture of boosting productivity. This is ATT which is statistically significant. The additional average gain for adopters at household level due to SSF adoption is about ETB 11827 per average lactation period (1.76*2 cows*14 ETB*240days) where 2 is the average milking cow, 14 
Table 6 Endogenous switching for FSF adoption and animal sale market participation

\begin{tabular}{|c|c|c|c|}
\hline \multirow[t]{2}{*}{ Variables } & \multirow{2}{*}{$\begin{array}{l}(\mathrm{FSF}=1) \\
\text { participation }\end{array}$} & \multirow{2}{*}{$\begin{array}{l}(\mathrm{FSF}=0) \\
\text { Participation }\end{array}$} & \multirow{2}{*}{$\begin{array}{l}(\mathrm{FSF}=1 / 0) \\
\text { Selection }\end{array}$} \\
\hline & & & \\
\hline Distance to market (walking minutes) & $0.000197(0.00180)$ & $0.00262^{*}(0.00137)$ & $\begin{array}{l}-0.000370 \\
(0.00126)\end{array}$ \\
\hline Distance to nearest road (walking minutes) & $0.00186(0.00260)$ & $0.000615(0.00193)$ & $\begin{array}{l}-0.00338^{*} \\
(0.00187)\end{array}$ \\
\hline Population density (ratio) & $\begin{array}{l}-0.000125 \\
(0.000117)\end{array}$ & $\begin{array}{l}-0.000142^{*}(8.17 \mathrm{e}- \\
05)\end{array}$ & $0.000109(8.21 e-05)$ \\
\hline Household head age (year) & $0.00356(0.00587)$ & $0.00432(0.00543)$ & $-0.00853(0.00523)$ \\
\hline Household head sex (male $=1$ ) & $-0.281(0.239)$ & $0.0124(0.204)$ & $0.563^{* * *}(0.174)$ \\
\hline Family size (number) & $0.00752(0.0386)$ & $0.0950^{* * *}(0.0340)$ & $0.00707(0.0283)$ \\
\hline Household head education (literate $=1$ ) & $0.111(0.172)$ & $-0.0786(0.153)$ & $-0.0407(0.137)$ \\
\hline Total oxen number & $-0.0289(0.0540)$ & $-0.118^{* *}(0.0572)$ & $0.0218(0.0440)$ \\
\hline Total cow number & $0.130^{*}(0.0718)$ & $0.0595(0.0547)$ & $-0.00641(0.0458)$ \\
\hline Farm size (ha) & $0.101(0.114)$ & $-0.0839(0.0965)$ & $0.0646(0.0629)$ \\
\hline Breed cow possession (yes $=1$ ) & $-1.028^{* * *}(0.326)$ & $0.0187(0.868)$ & $1.849^{* * *}(0.334)$ \\
\hline $\begin{array}{l}\text { Information access (TV, radio, and mobile }= \\
\text { 1) }\end{array}$ & $-0.166(0.190)$ & $-0.196(0.216)$ & $0.423^{* * *}(0.164)$ \\
\hline Mean milk price (ETB) & $-0.000983(0.00306)$ & $-0.000483(0.00210)$ & $\begin{array}{l}-0.000862 \\
(0.00280)\end{array}$ \\
\hline Social network (got assistance $=1$ ) & $-1.48 \mathrm{e}-06(1.71 \mathrm{e}-05)$ & $-1.34 \mathrm{e}-05(1.72 \mathrm{e}-05)$ & $1.38 \mathrm{e}-05(1.63 e-05)$ \\
\hline Access to formal credit (yes $=1$ ) & $-0.0837(0.192)$ & $0.0857(0.168)$ & $0.0689(0.144)$ \\
\hline Province 1 (Southern) & $1.106^{* *}(0.439)$ & $0.439(0.362)$ & $-1.383^{* * *}(0.300)$ \\
\hline Province 2 (Eastern) & $-0.127(0.268)$ & $-0.0886(0.288)$ & $-0.459^{*}(0.279)$ \\
\hline Province 3 (Central) & $-0.146(0.267)$ & $-0.150(0.463)$ & $0.510^{*}(0.265)$ \\
\hline Province 4 (North west) & $0.502^{*}(0.277)$ & $0.189(0.275)$ & $-0.580^{* * *}(0.221)$ \\
\hline Location of household (highland $=1$ ) & $0.601 *(0.339)$ & $0.613^{* *}(0.310)$ & $-0.585^{* *}(0.296)$ \\
\hline Animal shock experience (yes $=1$ ) & $-0.527^{* * *}(0.197)$ & $-0.120(0.211)$ & $0.435^{* * *}(0.159)$ \\
\hline $\begin{array}{l}\text { Distance to free grazing land (walking } \\
\text { minute) }\end{array}$ & & & $\begin{array}{l}0.00515^{* * *} \\
(0.00152)\end{array}$ \\
\hline Exposure of SF (years) & & & $0.214^{* * *}(0.0504)$ \\
\hline Constant & $0.698(0.467)$ & $-0.899^{*}(0.503)$ & $-1.356^{* * *}(0.506)$ \\
\hline rho1, rho0 & $-14.19(1.550)^{* * *}$ & $-0.625(0.519)$ & \\
\hline LR test of indep. eqns (PV & & 0.0005 & \\
\hline Observations & 518 & 518 & 518 \\
\hline
\end{tabular}

$P$ values are for slopes: ${ }^{* *} P<0.01,{ }^{* *} P<0.05$, and ${ }^{*} P<0.10=$ significant at $1 \%, 5 \%$, and $10 \%$ probability level, respectively

is the price of milk per liter, and 240 days is an average lactating period in the study area. This is consistent with the idea that adoption of new agricultural technology can improve household welfare (Shiferaw et al. 2014; Khonje et al. 2015; Wambugu et al. 2011; Hadush and Hagos 2018).

Likewise, the ATT and ATU shows that households who adopted FSF use $294 \mathrm{~kg}$ manure and those who did not adopt SF would have used about $34 \mathrm{~kg}$ manure in the case of FSF and $2444 \mathrm{~kg}$ less under SSF if they had adopted, which is theoretically consistent that confinement of cattle leads to increased quantities of manure (Rehnström 1999), whose finding indicated that over $90 \%$ of farmers with zero-grazed cattle utilized manure, compared to only $21 \%$ with free-grazing animals confined at night. 
Table 7 Endogenous switching for FSF adoption and input use

\begin{tabular}{|c|c|c|c|}
\hline \multirow[t]{2}{*}{ Variables } & \multirow{2}{*}{$\begin{array}{l}(\mathrm{SSF}=1) \\
\text { Propensity hire } \\
\text { labor }\end{array}$} & \multirow{2}{*}{$\begin{array}{l}(\mathrm{SSF}=0) \\
\text { Propensity hire } \\
\text { labor }\end{array}$} & \multirow{2}{*}{$\begin{array}{l}(\mathrm{SSF}=1 / 0) \\
\text { Selection }\end{array}$} \\
\hline & & & \\
\hline Farm income (ETB) & $-1.22 \mathrm{e}-06(3.81 \mathrm{e}-06)$ & $9.36 \mathrm{e}-06(7.53 \mathrm{e}-06)$ & $2.28 \mathrm{e}-06$ (4.03e-06) \\
\hline Off farm income (ETB) & $\begin{array}{l}-6.65 \mathrm{e}-06^{*}(3.94 \mathrm{e}- \\
06)\end{array}$ & $-7.96 \mathrm{e}-06(8.76 \mathrm{e}-06)$ & $3.62 \mathrm{e}-06^{*}(2.11 \mathrm{e}-06)$ \\
\hline Area of cultivated land (ha) & $6.29 e-05(0.000191)$ & $\begin{array}{l}-0.000420 \\
(0.000260)\end{array}$ & $\begin{array}{l}-0.000272^{* *} \\
(0.000130)\end{array}$ \\
\hline Farm tool value (ETB) & $\begin{array}{l}-0.000144^{* *}(6.68 \mathrm{e}- \\
05)\end{array}$ & $-1.21 \mathrm{e}-06(8.31 \mathrm{e}-05)$ & 4.25e-05 (4.91e-05) \\
\hline Number of oxen & $0.235^{* * *}(0.0625)$ & $0.170^{*}(0.0885)$ & $-0.0358(0.0490)$ \\
\hline Total farm size (ha) & $-0.0527(0.0644)$ & $-0.0117(0.143)$ & $0.0381(0.0600)$ \\
\hline Family labor (h) & $0.00430^{* *}(0.00170)$ & $-0.00484^{*}(0.00288)$ & $0.00448^{* * *}(0.00121)$ \\
\hline Family size (number) & $0.0545(0.0489)$ & $-0.0389(0.0501)$ & $0.0223(0.0307)$ \\
\hline Household head age (year) & $-0.00149(0.0432)$ & $0.0169(0.0511)$ & $-0.0660^{* *}(0.0312)$ \\
\hline Household head age square (year) & $9.79 e-05(0.000383)$ & $\begin{array}{l}-9.17 \mathrm{e}-05 \\
(0.000402)\end{array}$ & $0.000402(0.000265)$ \\
\hline Total herd size in TLU & $0.00798(0.0513)$ & $0.209^{* * *}(0.0616)$ & $-0.0690^{* *}(0.0342)$ \\
\hline Number of cows & $0.231^{* *}(0.112)$ & $-0.194(0.135)$ & $0.222^{* * *}(0.0711)$ \\
\hline Household head sex $($ male $=1)$ & $0.165(0.294)$ & $0.340(0.255)$ & $0.253(0.172)$ \\
\hline Household head education (literate $=1$ ) & $-0.0714(0.186)$ & $-0.466^{*}(0.254)$ & $0.294^{* *}(0.136)$ \\
\hline Access to formal credit (yes $=1$ ) & $-0.286(0.246)$ & $-0.374(0.278)$ & $0.187(0.152)$ \\
\hline $\begin{array}{l}\text { Distance to free grazing land (walking } \\
\text { minute) }\end{array}$ & $-0.00240(0.00287)$ & $0.00497(0.00666)$ & $0.0145^{* * *}(0.00225)$ \\
\hline Location of household (highland $=1$ ) & $-0.543(0.471)$ & $0.228(0.435)$ & $-0.372(0.333)$ \\
\hline Province 1 (Southern) & $1.032^{* * *}(0.340)$ & $1.898^{* * *}(0.503)$ & $-0.733^{* * *}(0.237)$ \\
\hline Province 2 (Eastern) & $0.627^{*}(0.356)$ & $0.200(0.588)$ & $-0.720^{* *}(0.297)$ \\
\hline Province 3 (Central) & $-1.201 * *(0.524)$ & $-0.378(0.756)$ & $-0.0213(0.299)$ \\
\hline Province 4 (North west) & $1.264^{* * *}(0.372)$ & $0.736(0.635)$ & $-0.713^{* * *}(0.245)$ \\
\hline Animal shock experience (yes $=1$ ) & & & $0.605^{* * *}(0.181)$ \\
\hline Exposure of SF (years) & & & $0.264^{* * *}(0.0701)$ \\
\hline Constant & $-2.190^{*}(1.224)$ & $-1.905(2.185)$ & $0.635(1.006)$ \\
\hline rhol, rhoo & $-0.237(0.416)$ & $0.0309(0.673)$ & \\
\hline LR test of indep. eqns (PV & & 0.8523 & \\
\hline Observations & 518 & 518 & 518 \\
\hline
\end{tabular}

$P$ values are for slopes: ${ }^{* *} P<0.01,{ }^{*} P<0.05$, and ${ }^{*} P<0.10=$ significant at $1 \%, 5 \%$, and $10 \%$ probability level, respectively

\section{Impact of FSF adoption on milk and meat consumption expenditure}

Referring to Table 3, the ESR estimate for the milk and meat product consumption expenditure indicated that the correlation coefficients between the error terms in the selection and the outcome equations $\left(\rho_{1}\right.$ and $\rho_{2}$ ) are not statistically different from zero, implying that the switch is not endogenous, and suggesting that adopting and nonadopting farmers' consumption expenditure is not different from an individual randomly drawn from the whole sample. Expectedly, results from the ESR indicate that total food expenditure, herd size, and gender have a significant positive effect on consumption expenditure for both groups of adopters. An increase in household herd size 
Table 8 Impact of SF on economic, ecological, and social welfare indicators

\begin{tabular}{|c|c|c|c|c|c|c|c|}
\hline \multirow[t]{2}{*}{ Outcome indicator } & & \multicolumn{2}{|c|}{ Decision on $\mathrm{FSF}^{\mathrm{a}}$} & \multirow{2}{*}{$\begin{array}{l}\text { Treatment } \\
\text { effect }\end{array}$} & \multicolumn{2}{|c|}{ Decision on $\mathrm{SSF}^{\mathrm{b}}$} & \multirow{2}{*}{$\begin{array}{l}\text { Treatment } \\
\text { effect }\end{array}$} \\
\hline & & Adopt & $\begin{array}{l}\text { Not- } \\
\text { adopt }\end{array}$ & & Adopt & $\begin{array}{l}\text { Not- } \\
\text { adopt }\end{array}$ & \\
\hline \multirow[t]{2}{*}{ Milk production $(\mathrm{L})$} & Participants & 2.4661 & 2.0198 & $0.4462^{* * *}$ & 1.9045 & -0.1487 & $2.0533^{* *}$ \\
\hline & $\begin{array}{l}\text { Non- } \\
\text { participants }\end{array}$ & 4.4336 & 2.1350 & $2.2986^{* * *}$ & 2.2169 & 1.2217 & $0.9952^{* * *}$ \\
\hline \multirow[t]{2}{*}{ Milk yield } & Participants & 1.6993 & 1.4064 & $0.2928^{* * *}$ & 1.7419 & -0.0210 & $1.7630^{* * *}$ \\
\hline & $\begin{array}{l}\text { Non- } \\
\text { participants }\end{array}$ & 2.1696 & 1.4592 & $0.7104^{* * *}$ & 0.2884 & 1.3935 & $-1.1051^{* * *}$ \\
\hline \multirow[t]{2}{*}{ Lactation in months } & Participants & 8.4598 & 8.1712 & $0.2886^{* * *}$ & 8.3298 & 8.7293 & $-0.3995^{* * *}$ \\
\hline & $\begin{array}{l}\text { Non- } \\
\text { participants }\end{array}$ & 8.6022 & 7.6087 & $0.9935^{* * *}$ & 8.3292 & 7.2554 & $1.0737^{* * *}$ \\
\hline \multirow{2}{*}{$\begin{array}{l}\text { Milk and meat } \\
\text { consumption }\end{array}$} & Participants & 1855.6 & 1587.9 & $267.7^{* * *}$ & 1807.8 & 1254.5 & $553.2^{* * *}$ \\
\hline & $\begin{array}{l}\text { Non- } \\
\text { participants }\end{array}$ & 2777.4 & 1548.9 & $1228.4^{* * *}$ & 2141.8 & 1470.3 & $671.5^{* * *}$ \\
\hline \multirow[t]{2}{*}{ Manure use in KG } & Participants & 1061.1 & 767.14 & $294.01^{* * *}$ & 1338.6 & 1080.5 & $258.08^{* * *}$ \\
\hline & $\begin{array}{l}\text { Non- } \\
\text { participants }\end{array}$ & 905.90 & 939.90 & -34.005 & - & 1022.7 & $-2444 . * * *$ \\
\hline \multirow[t]{2}{*}{ Herd size in TLU } & Participants & 3.9527 & 5.1053 & $-1.1525^{* * *}$ & 4.2433 & 4.5725 & $-0.3292^{* * *}$ \\
\hline & $\begin{array}{l}\text { Non- } \\
\text { participants }\end{array}$ & 4.7066 & 4.0789 & $0.6277^{* * *}$ & 4.5145 & 3.7701 & $0.7444^{* * * *}$ \\
\hline \multirow[t]{2}{*}{ Number of trees planted } & Participants & 37.434 & 25.965 & $11.468^{* * *}$ & 124.4 & 17.72 & $-9.636^{* * *}$ \\
\hline & $\begin{array}{l}\text { Non- } \\
\text { participants }\end{array}$ & 48.093 & 11.557 & $36.536^{* * *}$ & -181.4 & 13.64 & $30.156^{* * *}$ \\
\hline \multirow{2}{*}{$\begin{array}{l}\text { Conservation structure } \\
\text { length }\end{array}$} & Participants & 121.24 & 91.955 & $29.287^{* *}$ & 114.30 & 100.79 & 13.504 \\
\hline & $\begin{array}{l}\text { Non- } \\
\text { participants }\end{array}$ & 224.37 & 90.382 & $133.98^{* * *}$ & 140.18 & 85.550 & $54.635^{* * *}$ \\
\hline \multirow[t]{2}{*}{ Milking cows } & Participants & ATT & & $0.2316^{* *}$ & & & $0.2166^{* * *}$ \\
\hline & $\begin{array}{l}\text { Non- } \\
\text { participants }\end{array}$ & ATU & & $-0.0433^{* * *}$ & & & $0.1618^{* * *}$ \\
\hline \multirow[t]{2}{*}{ Plant $(1 / 0)$} & Participants & ATT & & $0.1939^{* * *}$ & & & $0.0819^{* * *}$ \\
\hline & $\begin{array}{l}\text { Non- } \\
\text { participants }\end{array}$ & ATU & & 0.0063 & & & $0.1256^{* * *}$ \\
\hline \multirow[t]{2}{*}{ Hired labor (1/0) } & Participants & ATT & & $-0.2923^{* * *}$ & & & $0.0577^{* * *}$ \\
\hline & $\begin{array}{l}\text { Non- } \\
\text { participants }\end{array}$ & ATU & & $0.3384^{* * *}$ & & & $0.1522^{* * *}$ \\
\hline \multirow{2}{*}{$\begin{array}{l}\text { Purchase of animal feed } \\
(1 / 0)\end{array}$} & Participants & ATT & & $-0.3122^{* * *}$ & & & $-0.3805^{* * *}$ \\
\hline & $\begin{array}{l}\text { Non- } \\
\text { participants }\end{array}$ & ATU & & $-0.0201^{*}$ & & & $0.1499^{* * *}$ \\
\hline \multirow[t]{2}{*}{ Animal sale (1/0) } & Participants & ATT & & $0.2945^{* * *}$ & & & $0.1604^{* * *}$ \\
\hline & $\begin{array}{l}\text { Non- } \\
\text { participants }\end{array}$ & ATU & & $0.4782^{* * *}$ & & & $0.4061^{* * *}$ \\
\hline \multirow[t]{2}{*}{ Animal shock(1/0) } & Participants & $\mathrm{ATT}$ & & $-0.1990^{* * *}$ & & & $-0.1047^{* * *}$ \\
\hline & $\begin{array}{l}\text { Non- } \\
\text { participants }\end{array}$ & ATU & & $0.2361^{* * *}$ & & & $0.3274^{* * *}$ \\
\hline
\end{tabular}

NB: $P$ values are for slopes: ${ }^{* *} P<0.01,{ }^{*} P<0.05$, and ${ }^{*} P<0.10=$ significant at $1 \%, 5 \%$, and $10 \%$ probability level, respectively

${ }^{\mathrm{b}} \mathrm{SSF}$ seasonal stall feeding adoption 
results in an increment of 155 ETB consumption expenditure for adopters while higher total food expenditure contributes positively to consumption expenditure.

This finding is in consonance with economic theory, which posits that farmers with higher asset spend more on consumer goods and is in conformity with the literature findings of milk consumption expenditure (Oni and Fashogbon 2012; Aidoo et al. 2009). A similar relationship was also reported in Kenya where dairy cow ownership increased consumption of milk products by $1.0 \mathrm{~L}$ per week (Nicholson et al. 2004). The results also showed that adopting male farmers recorded a significant consumption expenditure in milk and milk products in line with the results of Oni and Fashogbon (2012). A positive effect was observed between household total food expenditure and the level of milk consumption expenditure. This finding was in agreement with the result of Oni and Fashogbon (2012), where they reported that as food expenditure increases the consumption of milk and milk products expenditure increases in Nigeria.

We also observe a positive and significant impact of SF on households' milk and milk product consumption expenditure. The same Table 8 shows that farmers who adopt FSF and SSF would have spent about 268 ETB and 553 ETB less on meat and milk products if they had not adopted. The ATU estimates show that farm households who did not adopt would have spent about 1228 ETB more on meat and milk products if they had adopted. Our results are similar to previous studies that have used different estimation methods and have found a positive effect of stall feeding on the use of inputs (Wambugu et al. 2011) in Kenya and (Turinawe et al. 2011) in Uganda.

\section{Impact of FSF adoption on milking cow and total herd size}

The second stage results from Table 4 report the estimates of ESR for milking cow ownership outcome. There are differences between what determines milking cow ownership for adopters and non-adopters. The results of the correlation coefficients ( $\rho 1$ and $\rho 0$ ) indicate the absence of selection bias in the selection and outcome models, implying that unobserved factors do not substantially affect both the adoption decision and these two milking cow indicators. Our results basically pinpoint the roles of farm size, farm income, and herd size that are positive and significantly different from zero, suggesting that farmers that are not liquidity constrained with large herd size and land size are more likely to own more milking cows while access to information and credit reduced the probability of owning milking cow for non-adopters.

The results indicate that adopting farmers with large farm size and herd size has $36 \%$ and $40 \%$ of extra probabilities to own milking cows. This result is consistent with that is found by previous studies in Ethiopia (Tegebu et al. 2012). The result further stated that the size of land influences the number of animals by increasing household income which in turn increases investment in livestock and by producing animal feed. Both access to information and credit variables are inversely related to a probability of owning milking cow in the case of non-adopters. The coefficient is negative and statistically significant. This contradicts with Tegebu et al. (2012) who found that access to credit has a positive effect on cow ownership.

Moreover, non-adopting farmers living in the lowland areas are more likely to keep milking cows than farmers from the highland probably due to the fact that there is relatively large grazing land in the lowland compared to the highland. The result agrees 
with that of Tegebu et al. (2012), who found a negative relation between highland residency and cow ownership in the Ethiopian highlands. There is also a negative association between veterinary expenditure and adoption of milking cows for SF adopters. This could be due to the fact that more input expense increases liquidity constraint of households and hence lower the probability of owning breeding cattle. In line with this, Quddus (2013) found a negative association between adoption of dairy technology and input cost in Bangladesh.

The results from the ESR regression (Table 8) indicate that the probability of owning milking cow due to the adoption of FSF and SSF among farmers who actually adopted the technology is 23 and $21 \%$ respectively. A typical non-adopter would own $16 \%$ more milking cows if they were to adopt the SF technology (Table 8). Other studies also established a significant link between the adoption of SF and improved cow ownership in Ethiopia, Tanzania, and Uganda (Benin et al. 2006; De Cao et al. 2013; Holtland 2007; Turinawe et al. 2011). The ATT estimate for the SF, however, suggests that SF reduces household total herd size ownership by $1 \mathrm{TLU}$, representing a $22.6 \%$ decrement in cattle possession, as noted by Holtland (2007) and Ogle (2001) in Tanzania who found a negative relation between stall feeding and herd size. The ATU results from ESR also indicate that non-users would have increased herd size by $15.5 \%$ had they adopted SF.

\section{Impact of FSF adoption on land conservation and plantation}

Similarly to many other environmentally vulnerable countries, Ethiopia has faced rampant land degradation in the form of immense of gully and soil erosion caused by overgrazing and deforestation (Teshome et al. 2016; Gessesse et al. 2016). In response to extensive degradation of the resource base, different land management measures such as stone terraces, soil bunds, and agroforestry practices on cultivated fields, as well as area closure have been introduced (Frankl et al. 2016) in the country. Ewnetu and Bliss (2010) and Teshome et al. (2016) mentioned that among others, demographic characteristics, farming practices, agro-ecological conditions, access to roads and markets, and land-use policies, property rights, and level of extension services are some of the critical factors affecting management investment decisions in Ethiopia. In view of this, the extent of determinants of tree-planting decisions as a land management strategy is examined in this section.

The ESR second-stage results as presented in Table 5 displayed that propensity to grow trees was significantly affected by some range of factors. The result clearly indicated that household size and family labor were positively and significantly correlated with the propensity to growing trees while hired labor results in lower willingness to plant trees. This finding is consistent with earlier studies by Alamirew (2011) and Gessesse et al. (2016), who both reported that family size had a positive and significant influence in adopting land management technology(tree planting) in Ethiopia. As shown in Table 5, distance to nursery and access to animal cart had negative and significant influences on tree-planting decisions in contrast to studies which confirmed that there was a positive and significant relationship between farm tool and land management technology adoption (Teshome 2016) in Ethiopia. The probability of growing trees was also strongly correlated with household age in contrast with Gessesse et al. (2016). 
Regarding land conservation, Table 8 demonstrates the significant and positive impact of ATT, implying that adopters of SF would increase their land conservation by 29 $\mathrm{m}$ of physical construction. Similarly, the ATU value of $134 \mathrm{~m}$ signifies that nonadopters would increase land conservation if FSF was adopted by non-adopters for cattle farming. The result also shows that the mean value of planted trees of SF adoption is statistically higher than had they not been adopted. SF adoption increases tree plantation by about 11 trees per plot. For non-adopters, the mean planted tree would have been increased by 36.5 trees had they adopted FSF. This is consistent with the result from Garcia et al. (2008) and Nyssen et al. (2007), whose result revealed that the practice of SF was ecologically sustainable. In summary, non-adopters would improve land conservation from being adopters than remaining as non-adopters, indicating that the decision to adopt SF seems to be rational.

\section{Impact of FSF adoption on animal and animal product sale market participation}

The ESR empirical results for the probability of participating in animal and animal product sale in Table 6 showed that participation in animal and animal products markets were influenced to a great extent by family size, distance to market, cattle size, population density, animal shock, highland location, and zonal variation and not so much by human capital. Farmers with more family member and cow number living in the highland participated more in an animal market. However, ownership of oxen and animal shock experience reduced participation in the market for animals and animal product. These findings reinforce the findings of Ehui et al. (2003) and Kuma et al. (2014) where they found that oxen holding reduced dairy product sale while cow stock increased live animal or dairy product sale in Ethiopia.

A negative relationship was also reported between population density and market participation since areas with greater population pressure are associated with lower sales of live animals (Ehui et al. 2003). In a similar study area, Ehui et al. (2003) also showed that farmer participation in livestock markets sales was positively associated with long distance to market and higher population density. As expected, animal shock exposure was found to have an inverse relationship with participation in the animal market. However, farmers living in the highland unexpectedly appeared to have a high probability of participation in an animal sale market than people from the lowland (Tegebu et al. 2012). In confirmation with our expectation, belonging to Southern and Northwestern zones, which are relatively endowed with population livestock in the region, increased the probability of participating in an animal market.

Consistent with our expectation, the results (Table 8) further show that adoption of SF significantly increased the probability of selling animal and animal product by $29 \%$ for adopters. For non-adopters, the ATU estimates show that the probability of market participating would have been $47 \%$ higher had they adopted the technology. A similar result was obtained by Wambugu et al. (2011) in Kenya and Turinawe et al. (2011) in Uganda who found a higher volume of animal and product sale in SF users.

\section{Impact of FSF adoption on input use and animal shock}

The ESR estimation result regarding labor market participation is presented in Table 7. The estimated model with LR chi2 value (0.32) significant indicates that there is no 
joint dependence between the selection equations and the outcome equations for adopters and non-adopters (Table 7). The result revealed that the labor market participation of household is significantly related to a number of factors including off-farm income, farm tool value, family labor, herd size, the total number of cows and oxen, education, and zonal variation. With regards to household family labor, the variable carries different signs in both of the participation regimes. Family labor has a positive significant effect on the probability of participation for adopters. However, the labor market participation responded negatively and significantly to family labor in the case of non-adopters. A similar relationship was reported in Ethiopia where family adult labor responded positively to the propensity of hiring labor (Bedemo et al. 2013).

The variables representing farm resource endowments such as total cattle owned, the number of oxen and cows, and the value of farm inputs affect the probability of participation in different market regimes differently and most of these variables carry the expected sign. An increase in the size of cattle encourages the probability of hiring labor in both regimes. As a result, it shows a positive and significant effect in both regimes. However, the value of farm tool has a negative significant impact on participation in the adopting regime because households with a very high number of cattle mostly participate in hiring labor, whereas the value of variable farm input has a negative and significant effect on hiring. This is in line with that of the previous empirical result (Bedemo et al. 2013) in the case of herd size and opposite in the case of farm tool value.

With regards to education, the result reveals that households with better-educated head have a lower propensity to participate in labor markets as compared to illiterate households. A result that is consistent with other studies in the literature, which found that education facilitates participation in the labor market (Agwu et al. 2014), but contrasts with the result of Bedemo et al. (2013). It is also interesting to see that the likelihood of a farmer to hire labor is significantly higher for those living in the southern and North West zone but lower for farmers from Central which relatively have lower cattle and land size. The differences in the participation equation coefficient among the farm households who live in different zones illustrate the presence of heterogeneity in the sample.

One of the main hypothesized impacts of SF is increased household input use such as labor and feed. The results from the ESR probit in Table 8 indicate that the treatment effects for the propensity to hire labor are significantly negative. Adopting households have a $29 \%$ lower probability of hiring labor compared with the counterfactual case of not participating in the case of SSF. Those who actually did not adopt would also have a 33\% higher probability of hiring labor in the case that they did adopt the technology. Our results are similar to previous studies. Wambugu et al. (2011) in their study showed that the confinement system required considerably higher labor inputs than free grazing in Kenya, and labor requirements for dairy cows are met primarily by an increase in hired labor (Nicholson 1999) in Kenya. The ATT from ESR results also show that the adoption of SF decreased the propensity to buy extra animal feed by $31 \%$ for adopters in contrast to previous studies (Wambugu et al. 2011).

Regarding animal shock, the ATT results show that adoption of SF decreased the probability of shock exposure by $19 \%$ in the case of FSF. Likewise, the ATU results also indicate that non-adopters would benefit less had they adopted FSF and the probability of shock exposure would decline by $23 \%$ as Bishu (2014) anticipated that SF adoption reduces the risk of animal death in Ethiopia. 


\section{Summary and conclusion}

So far, the economic benefits of SF on household's welfare are neither properly documented nor proper impact evaluation design was followed. This paper is the first to quantify the impact of full stall feeding (FSF) using proper impact evaluation approach perhaps in Africa but particularly in East Africa, which is ultimately what policy-makers seek to know. The novelty of this paper lies in distinguishing the impact of both full (FSF) and seasonal (SSF) stall feeding on economic, ecological, and social outcome variables. The richness of our dataset also consistently enabled us to identify the economic, ecological, and social responses to SF so that we are able to contribute to filling a key gap in the dairy intensification literature. The use of proper impact evaluation approach based on an agricultural household model framework is an extra contribution to the literature.

In this paper, efforts were made to the impact of full (FSF) and seasonal (SSF) stall feeding technology on households' economic, ecological, and social welfare outcome indicators in rural Northern Ethiopia using data of 518 rural farmers obtained from 2015 Tigrai rural household survey by applying endogenous switching regression model. First, existences of initial differences in explanatory and outcome variables among households were examined using descriptive analysis of the data. The overall result indicated that SF adoption ensures mixed benefits in response to differences in factor endowments, household characteristics, farm attributes, and location factors, which create differences in marginal benefit, and the resulting differences in marginal benefit induce farm households to adopt SF.

We found that SF adoption is positively influenced by animal feed value, zonal variation, male headship, family size, off-farm income, access to information and fodder shed, forage expense, breed cow possession, animal shock, distance to grazing land, and early SF exposure, but negatively associated with total land and herd size, highland location, and longer distance to road. The result also indicates that adoption of an improved cow, availability of grazing land, family and hired labor, agro-ecology, and access to animal and fodder shed determine the amount of milk production. With regard to milk and milk product consumption expenditure, the findings have revealed that household total food expenditure, herd size, and male headship has been proven to increase consumption expenditure. We further found that propensity to keep milking cows (local and breed) is mainly determined by agroecology and veterinary expense, farm income, herd and farm size, access to information, and credit.

In examining factors affecting animal market participation for sales, the results show that physical capital (ownership of cattle), population density, family size, agroecology location, distance to market, and animal shock experience are the main factors influencing market participation in animal sales. The result of Endogenous Switching Probit analysis revealed that the probability of hiring labor was influenced by variables such as financial capital (off-farm income and farm tool value), resource endowment (herd size and labor), agroecology attributes, and human capital. In connection with the land investment, tree planting and physical structure decisions were highly significantly affected, among others, by household size and age, family and hired labor force availability, distance to the nursery, access to farm cart, and willingness to invest.

Using ESR models, we estimate different welfare outcome indicators for both adopters from adoption (ATT), and non-adopters had they adopted (ATU). The adoption of FSF and SSF leads to significant gains in milk production and consumption 
expenditure, lactation period, input use (labor, manure and feed), tree plantation and soil conservation, milking cow possession, and animal market participation but loses in terms of cattle stock size. It is identified that there would be a decline of $21 \%$ in milk production if adopters would not have adopted this technology. On the other hand, non-adopters could increase their milk production and productivity by $100 \%$ and $48 \%$ if they would adopt this technology. The results further show that SF adoption had significant lactation period-increasing impacts for adopters and non-adopters if they were to adopt the technology.

An increase of consumption expenditure by $17 \%$ from FSF and $44 \%$ in the case of SSF could be considered significant on livelihoods for smallholder farmers in Tigrai and such a positive impact should not be ignored. On average, adoption of SF increased manure use in the range of 258-294 $\mathrm{kg}$ for adopters. Regarding input use, the adoption of SF was to decrease the propensity of hiring labor by $29 \%$ and purchasing animal feed by $31 \%$, suggesting that SF is an input-saving in areas facing feed shortage and this is a significant contribution to ensuring milk production and consumption. In line with our expectation, we have found that participation in SF, on average, increased the probability of keeping milking cow by $23 \%$ but decreased total cattle stock by 1 TLU. Among adopters, the adoption of SF increased the likelihood of participating in an animal sale market by $29 \%$ while non-adopters would have increased their participation by $47 \%$ had they decided to adopt.

Along with the positive biophysical and environmental benefits of the adoption of SF, which are well documented in the literature, the adoption of SF leads to a gain in a number of plants of 11 trees and $29 \mathrm{~m}$ of physical construction for the typical adopter and 36 trees and $133 \mathrm{~m}$ if the typical non-adopter were to adopt the SF technology. The adoption process also increased the propensity of growing trees by $19 \%$ and decreased household animal shock experience by a probability of $19 \%$ for adopters and about $15 \%$.

These findings demonstrate the importance of SF technology for enhancing livestock production (milk, manure production and consumption, lactation), market participation (live animal and animal products' sale), land investment (plantation and soil construction), input use (feed and labor), and animal shock exposure of smallholder farmers in semi-arid areas. Therefore, wider adoption of SF has great potential for transforming the agricultural sector in general and the welfare of small rural farmers in the region. The policy implication of our results is that the national government should consider embracing SF as one of the priority farming packages in its national extension agenda and develop policies which overcome limitations for wider expansion.

The impact of SF technology on land cultivation and crop production across various livestock systems, agroecology, and land characteristics is not fully understood. The lack of longitudinal data also limits the relevance of the findings to check for the dynamic impacts of SF on the given outcome variables. Besides, the author believes that there are better indicators of welfare than those used in this paper. Therefore, a future research should focus on adopting an approach using good welfare indicators (nutrition, incidences of malnourishment, daily calorie intake, and diversity of food intake) to proxy food security. In addition, a research that uses the lag value of outputs than current output in the estimation based on longitudinal data will be a plus for this paper. 
Author's contributions

This author is fully responsible for the production of this article. The author read and approved the final manuscript.

\section{Funding}

This research was funded by the Norwegian Agency for Development Cooperation (NORAD) and the Quota Scholarship programme of StatensLånekasse for Utdannin during the design of the study and collection, analysis, and interpretation of data.

\section{Availability of data and materials}

The dataset used in this paper is available and accessible upon request from the corresponding author.

\section{Competing interests}

The corresponding author declares that there are no competing interests.

Received: 4 April 2017 Revised: 30 January 2019

Accepted: 21 October 2020 Published online: 03 May 2021

\section{References}

Adane Z, Shiferaw K, Gebremedhin B (2015) Sources of technical inefficiency of smallholder farmers in milk production in Ethiopia, LIVES Working Paper 3. ILRI, Nairobi

Agwu NM, Nwankwo EE, Anyanwu Cl (2014) Determinants of agricultural labour participation among youths in Abia State, Nigeria. Int J Food Agric Econ 2(1):157-164

Aidoo R, Nurah GK, Fialor SC, Ohene-Yankyera K (2009) Determinants of dairy consumption expenditure in urban communities of Southern Ghana. J Sci Technol 29(1):87-96

Alamirew B (2011) The impact of poverty, tenure security and risk on sustainable land management strategies in north central Ethiopia: analysis across three agro-ecological zones. J Sustain Dev Afr 13:227-240

Alene AD, Manyong VM (2007) The effects of education on agricultural productivity under traditional and improved technology in northern Nigeria: an endogenous switching regression analysis. Empir Econ 32(1):141-159

Asresie A, Zemedu L (2015) The contribution of livestock sector in Ethiopian economy. A review. Adv Life Sci Technol 29:990

Ayenew HY, Sauer J, Abate-Kassa G (2015) Exposure to risk and risk management in smallholder agriculture. In 55th Annual Conference, Giessen, Germany, (No. 209211). German Association of Agricultural Economists

Baltenweck I, Tenywa JS, Mugisha J (2007) Dairy farming in Uganda: production efficiency and soil nutrients under different farming systems, vol 1. ILRI (aka ILCA and ILRAD), Nairobi

Bedemo A, Getnet K, Kassa B (2013) Determinants of labor market participation choice of farm households in rural Ethiopia: multinomial logit analysis. J Econ Sustain Dev 4(1):133-141

Behnke RH, Metaferia F (2011) The contribution of livestock to the Ethiopian economy_-part II.IGAD livestock policy initiative, IGAD LPI working paper no. 02-11. IGAD, Djibouti

Benin S, Ehui S, Pender J (2006) Policies for livestock development in the Ethiopian Highlands. In: Chapter 6 in International Food Policy Research Institute (ed) Strategies for sustainable land management in the East African Highlands. IFPRI, Nairobi, pp 141-165

Bishu KG (2014) Risk management and the potential of cattle insurance in Tigray, Northern Ethiopia. Ph.D. Thesis, University College Cork

Blundell R, Costa Dias M (2000) Evaluation methods for non-experimental data. Fisc Stud 21(4):427-468

Cary J, Webb T, Barr N (2001) The adoption of sustainable practices: some new insights. An analysis of drivers and constraints for the adoption of sustainable practices derived from research. Bureau of Rural Sciences, Canberra

Cecchi G, Wint W, Shaw A, Marletta A, Mattioli R, Robinson T (2010) Geographic distribution and environmental characterization of livestock production systems in Eastern Africa. Agric Ecosyst Environ 135(1):98-110

CSA (2010) Agricultural sample survey, land utilization, private peasant holdings, meher season, Central Statistical Agency (CSA), Statistical Bulletin Vol. VI, No. 468, Addis Ababa, Ethiopia

CSA (Central Statistics Authority) (2008) Central statistics authority of the Federal Democratic. The Republic of Ethiopia. Agricultural sample survey 2007/2008. Vol. II. Report on livestock and livestock characteristics. Statistical bulletin. Addis Ababa: CSA

De Cao E, van den Berg MM, Tile CY, Wondwosen T (2013) The effects of zero grazing in Ethiopia. In Proceedings of the CSAE Conference 2013: Economic Development in Africa, pp. 1-15

Del Corral J, Perez JA, Roibás D (2011) The impact of land fragmentation on milk production. J Dairy Sci 94(1):517-525

D'Emden FH, Llewellyn RS, Burton MP (2006) Adoption of conservation tillage in Australian cropping regions: an application of duration analysis. Technol Forecast Soc Chang 73(6):630-647

Deressa TT, Hassan RM, Ringler C, Alemu T, Yesuf M (2009) Determinants of farmers' choice of adaptation methods to climate change in the Nile Basin of Ethiopia. Glob Environ Chang 19(2):248-255

Devereux S (2014) Livestock and livelihoods in Africa: maximizing animal welfare and human wellbeing. Institute of Development Studies, Working Paper No 451. Brighton BN1 9RE, UK

Di Falco S, Veronesi M (2013) How can African agriculture adapt to climate change? A counterfactual analysis from Ethiopia. Land Econ 89(4):743-766

Diao X, Pratt AN (2007) Growth options and poverty reduction in Ethiopia-an economy-wide model analysis. Food Policy 32(2):205-228

Ehui S, Benin S, Paulos Z (2003) Policy options for improving market participation and sales of smallholder livestock producers: a case study of Ethiopia draft prepared for Presentation at the 27th Conference of the International Association of Agricultural Economists (IAAE), 16th-22nd August 2009, Beijing 
Ewnetu Z, Bliss JC (2010) Tree growing by small holder farmers in the Ethiopian Highlands. In Small scale forestry in changing world: Opportunities and challenges and the role of extension and technology transfer IUFRO conference (Vol. 3)

FAO (2007) TerrAfrica- a vision paper for sustainable land management in Sub-Saharan Africa. Food and Agriculture Organisation of the United Nations, Rome

FAO (2013) Milk and dairy products in human nutrition, milk and dairy products in human nutrition. FAO, Rome

FAO (2018) Food and agriculture organization of the United Nations. Gateway to dairy production and products. http://www. fao.org/dairy-production-products/production/dairy...en.

FAO (Food and Agriculture Organization of the United Nations) (2005) Production yearbook. FAO, Rome

FAO (Food and Agriculture Organization of the United Nations) (2009) Production yearbook. FAO, Rome http://faostat.fao. org/default.aspx

Fernandez-Cornejo J, Hendricks C, Mishra A (2005) Technology adoption and off-farm household income: the case of herbicide-tolerant soybeans. J Agric Appl Econ 37(3):549-563

Frankl A, Deckers J, Moulaert L, Van Damme A, Haile M, Poesen J, Nyssen J (2016) Integrated solutions for combating gully erosion in areas prone to soil piping: innovations from the Drylands of Northern Ethiopia. Land Degrad Dev 27(8):1797-1804

Garcia O, Balikowa D, Kiconco D, Ndambi A, Hemme T (2008) Milk production in Uganda. Dairy farming economics and development policy impacts. IGAD LPI, Working Paper No. 09- 08.

Gass GM, Sumberg JE (1993) Intensification of livestock production in Africa: experience and issues. University of East Anglia, Norwich

Gebremedhin B, Ahmed MM, Ehui SK (2003) Determinants of adoption of improved forage technologies in crop-livestock mixed systems: evidence from the highlands of Ethiopia. Trop Grasslands 37:262-273

Gebremedhin B, Hirpa A, Berhe K (2009) Feed marketing in Ethiopia: results of rapid market appraisal. Improving Productivity and Marketing Success (IPMS) of Ethiopian farmers project working paper 15. ILRI, Nairobi

Gebreselassie S, Kirui OK, Mirzabaev A (2016) Economics of land degradation and improvement in Ethiopia. In: Nkonya E, Mirzabaev A, von Braun J (eds) Economics of land degradation and improvement -a global assessment for sustainable development. Springer, Cham

Gessesse B, Bewket W, Bräuning A (2016) Determinants of farmers' tree-planting investment decisions as a degraded landscape management strategy in the central highlands of Ethiopia. Solid Earth 7(2):639-650

Ghadim AKA, Pannell DJ, Burton MP (2005) Risk, uncertainty, and learning in adoption of a crop innovation. Agric Econ 33(1): $1-9$

Gerber P, Vellinga T, Opio C, Steinfeld H (2011) Productivity gains and greenhouse gas emissions intensity in dairy systems. Livest Sci 139(1):100-108

Gunte KE (2015) Understanding factors affecting technology adoption in smallholder livestock production systems in Ethiopia: the role o farm resources and the enabling environment. Doctoral dissertation, Wageningen: Wageningen University

Hadush M (2018) Understanding farmers seasonal and full year stall feeding adoption in Northern Ethiopia. Rev Agric Appl Econ 21(1):23-39

Hadush M, Hagos BG (2018) The economic impact of stall feeding on cow milk production and calf death: empirical evidence from Northern Ethiopia. Asian J Agric Rural Dev 8(1):64-73

Hagos F (2003) Poverty, institutions, peasant behavior and conservation investment in Northern Ethiopia. Doctoral Dissertation. UMB School of Economics and Business. Norwegian University of Life Sciences. Dissertation no. 2003:2

Halderman MN (2004) The political economy of pro-poor livestock policy making in Ethiopia, FAO working paper No. 19. $\mathrm{FAO}$, Rome

Hausman JA (1978) Specification tests in econometrics. Econometrica 46:1251-1272

Headey D, Dereje M, Taffesse AS (2014) Land constraints and agricultural intensification in Ethiopia: A village-level analysis of high-potential areas. Food Policy 48(0):129-141

Heckman J (1979) Sample selection as a specification error. Econometrica 47:153-161

Heckman JJ (2001) Econometrics and empirical economics. J Econ 100(1):3-5

Herrero M, Grace D, Njuki J, Johnson N, Enahoro D, Silvestri S, Rufino MC (2013) The roles of livestock in developing countries. Animal 7(s1):3-18

Holden ST, Deininger K, Ghebru H (2011) Tenure Insecurity, gender, low-cost landcertification and land rental market participation. Journal of Development Studies 47(1):31-47

Holden ST, Westberg NB (2016) Exploring technology uses under climate risk and shocks through an experimental lens. Afr J Agric Resour Econ 11(1):47-62

Holtland G (2007) Eroded consensus: however-changing policy narratives distort the inter pretation of livelihood systems: the uneasy relationship between science and development, a case study from central Tanzania. NUFFIC and CIDIN Radboud University, The Netherlands

Huffman WE (1991) Agricultural household models: survey and critique. In: Hallberg MC, Findeis JL, Lass DA (eds) Multiple job-holding among farm families. lowa State University Press, Ames, pp 79-111

Ilyin S (2011) The Looming threat of overgrazing: effects and recommendations. Congressional Hunger Center. [Online] http://Hungercenter.wpengine.netdna-cdn.com/wp-content Looming-Threat-of-Overgrazing-llyin.pdf (Uploaded 09 2011)

Kabirizi JML (2006) Effect of integrating forage legumes in smallholder dairy farming systems on feed availability and animal performance. Unpublished Ph. D thesis, Makerere University, Uganda

Khonje M, Manda J, Alene AD, Kassie M (2015) Analysis of adoption and impacts of improved maize varieties in eastern Zambia. World Dev 66:695-706

Klitzing A, Das A, Bonzi M, Barro A, Langkamp U, Dereje K, Pale S, Nayak S, Gupta A (2014) Promoting best practice in agriculture: examples from Burkina Faso, Ethiopia, India and Europe.Deutsche Welthungerhilfe e.V., Friedrich-Ebert-Straße 1, 53173 Bonn.

Kuma B, Baker D, Getnet K, Kassa B (2014) Factors affecting market participation and volume of supply in Ethiopia. Asian J Rural Dev 4(1):1-15 
Lal R, Stewart BA (2010) Food security and soil quality. Advances in soil science. Taylor \& Francis Group, LLC/CRC Press, Boca Raton

Lenaerts $L$ (2013) Insights into agency and social interactions in natural resource management. Ph.D. Thesis, Wageningen University.

Lokshin M, Sajaia Z (2004) Maximum likelihood estimation of endogenous switching regression models. Stata J 4(3):282-289

Maarse LM (1997) The process of change in dairy husbandry extension: the case of coastal Kenya. MSc Thesis, Laren site in International Agricultural College and University of Reading, Deventer, Netherlands, and Reading, UK.

Makoni N, Mwai R, Redda T, van der Zijpp AJ, van der Lee J (2014) White gold: opportunities for dairy sector development collaboration in East Africa. Centre for Development Innovation, Wageningen

McIntire J, Bourzat D, Prabhu P (1992) Crop-livestock interaction in Sub-Saharan Africa. World Bank, Washington, DC

Meul M, Van Passel S, Fremaut D, Haesaert G (2012) Higher sustainability performance of intensive grazing versus zerograzing dairy systems. Agron Sustain Dev 32(3):629-638

Nalunkuuma J, Affognon H, Kingori SW, Salifu D, Njonge FK (2013) Adoption of zero grazing and impact on livestock keepers' knowledge of cattle reproductive parameters in Western Kenya. In African Crop Science Conference Proceedings (Vol. 11, pp. 599-604)

Nedessa B, Nyborg I, Ali J (2005) Exploring ecological and socio-economic issues for the improvement of area enclosure management. A case study from Ethiopia. Drylands Coordination Group, DCG Report No. 38

Nicholson CF (1999) Smallholder dairy technology in coastal Kenya: an adoption and impact study. ILRI Impact Assessment Series 5, ILRI. Nairobi, Kenya

Nicholson CF, Thornton PK, Muinga RW (2004) Household level impacts of dairy cow ownership in Coastal Kenya. J Agric Econ 55(2):175-195

Nyssen J, Descheemaeker K, Nigussie Haregeweyn MH, Deckers J, Poesen J (2007) Lessons learned from 10 years research on soil erosion and soil and water conservation in Tigray, Tigray Livelihood Papers No. 7, Mekelle

Odame H, Kimenye L, Kabutha C, Alemu D, Oduori LH (2013) Why the low adoption of agricultural technologies in Eastern and Central Africa?, ASARECA (Association for Strengthening Agricultural Research in Eastern and Central Africa), Entebbe, Uganda, 21 Oct 2011, pp 21-23

Ogle RB (2001) The need for social-economic and environmental indicators to monitor degraded ecosystem rehabilitation: a case study from Tanzania. Agric Ecosyst Environ 87(2):151-157

Oni O, Fashogbon A (2012) Rural household consumption of milk and products in Nigeria. J Agric Biol Sci 7(12):1062-1069

Otsuka K, Place F (2014) Changes in land tenure and agricultural intensification in sub-Saharan Africa, WIDER Working Paper 2014/051.

Quddus MA (2013) Adoption of dairy farming technologies by small farm holders: practices and constraints. Bangladesh 5 Anim Sci 41(2):124-135

Rehnström M (1999) Zero-Grazing and Soil Erosion in Kondoa Eroded Area, Tanzania. Minor Field Studies Report No. 68. Swedish University of Agricultural Sciences, International Office, Sweden.

Rogers EM (2003) Diffusion of innovations, 5th edn. Free Press, New York

Shiferaw B, Kassie M, Jaleta M, Yirga C (2014) Adoption of improved wheat varieties and impacts on household food security in Ethiopia. Food Policy 44:272-284

Singh I, Squire L, Strauss J (1986) Agricultural household models. Extension, applications, and policy. The Johns Hopkins University Press, Baltimore

Sserunkuuma D (2005) The adoption and impact of improved maize and land management technologies in Uganda. J Agric Dev Econ 2(1):67-84

Staal SJ, Waithaka M, Njoroge L, Mwangi DM, Njubi D, Wokabi A (2003) Costs of milk production in Kenya: Estimates from Kiambu, Nakuru and Nyandarua districts. SDP Research and Development, Report No.1 Smallholder Dairy Project

Tegebu FN, Mathijs E, Deckers J, Haile M, Nyssen J, Tollens E (2012) Rural livestock asset portfolio in northern Ethiopia: a microeconomic analysis of choice and accumulation. Trop Anim Health Prod 44(1):133-144

Tegegne A, Gebremedhin B, Hoekstra D, Belay B, Mekasha Y (2013) Smallholder dairy production and marketing systems in Ethiopia: IPMS experiences and opportunities for market-oriented development, IPMS Working Paper 31. ILRI, Nairobi

Tesfa A, Mekuriaw S (2014) The effect of land degradation on farm size dynamics and crop-livestock farming system in Ethiopia: a review. Open J Soil Sci 4(01):1-5

Teshome A, Graaff J, Ritsema C, Kassie M (2016) Farmers' perceptions about the influence of land quality, land fragmentation and tenure systems on sustainable land management in the north western Ethiopian highlands. Land Degrad Dev 27(4): 884-898

Turinawe A, Mugisha J, Kabirizibi J (2011) Socio-economic evaluation of improved forage technologies in smallholder dairy cattle farming systems in Uganda. J Agric Sci 4(3):163-174

Udo HMJ, Aklilu HA, Phong LT, Bosma RH, Budi Satria IGS, Patil BR, Bebe BO (2011) Impact of intensification of different types of livestock production in smallholder crop-livestock systems. Livest Sci 139(1):22-29

Wambugu S, Kirimi L, Opiyo J (2011) Productivity trends and performance of dairy farming in Kenya. Tegemeo Institute of Agricultural Policy and Development. Egerton University, Nairobi. pp. 45.

Wiebers UC (1992) economic and environmental effects of pest management information and pesticides: The case of processing tomatoes in California. PhD dissertation, Department of Agricultural Sciences, University of Berlin

World Bank (2008) World development report. In: Agriculture for development. The World Bank, Washington, DC

Yilma Z, Guernebleich E, Sebsibe A, Fombad R (2011) A review of the Ethiopian dairy sector. FAO Sub Regional Office for Eastern Africa (FAO/SFE), Addis Ababa

\section{Publisher's Note}

Springer Nature remains neutral with regard to jurisdictional claims in published maps and institutional affiliations. 